\title{
Comprehensive Review on Phytochemicals, Pharmacological and Clinical Potentials of Gymnema sylvestre
}

\section{OPEN ACCESS}

Edited by:

Monique S.J. Simmonds, Royal Botanic Gardens, Kew,

United Kingdom

Reviewed by:

Francisco Pérez García, University of Barcelona, Spain

Souaibou Yaouba,

Université de Lorraine, France

${ }^{*}$ Correspondence: Md. Moklesur Rahman Sarker moklesur2002@yahoo.com; dr.moklesur2014@gmail.com

Isa Naina Mohamed isanaina@yahoo.co.uk

Specialty section:

This article was submitted to

Ethnopharmacology,

a section of the journal

Frontiers in Pharmacology

Received: 24 May 2019 Accepted: 23 September 2019

Published: 29 October 2019

Citation:

Khan F, Sarker MMR, Ming LC, Mohamed IN, Zhao C, Sheikh BY, Tsong HF and Rashid MA (2019)

Comprehensive Review on

Phytochemicals, Pharmacological and Clinical Potentials of

Gymnema sylvestre.

Front. Pharmacol. 10:1223.

doi: 10.3389/fphar.2019.01223

\author{
Farzana Khan 1,2, Md. Moklesur Rahman Sarker,2*, Long Chiau Ming ${ }^{3,4}$, \\ Isa Naina Mohamed ${ }^{5 *}$, Chao Zhao ${ }^{6}$, Bassem Y. Sheikh ${ }^{7}$, Hiew Fei Tsong ${ }^{8}$ \\ and Mohammad A. Rashid ${ }^{9}$
}

\begin{abstract}
${ }^{1}$ Department of Pharmacy, State University of Bangladesh, Dhaka, Bangladesh, ${ }^{2}$ Pharmacology and Toxicology Research Division, Health Med Science Research Ltd., Dhaka, Bangladesh, ${ }^{3}$ PAPRSB Institute of Health Sciences, Universiti Brunei Darussalam, Bandar Seri Begawan, Brunei, ${ }^{4}$ Division of Pharmacy, School of Medicine, College of Health and Medicine, University of Tasmania, Hobart, TAS, Australia, ${ }^{5}$ Department of Pharmacology, Faculty of Medicine, Universiti Kebangsaan Malaysia (The National University of Malaysia), Cheras, Malaysia, ${ }^{6}$ College of Food Science, Fujian Agriculture and Forestry University, Fuzhou, China, ${ }^{7}$ Faculty of Medicine, Taibah University, Almadinah Almunawwarah, Saudi Arabia, ${ }^{8}$ Alpro Pharmacy and Powerlife, Port Dickson, Malaysia, ${ }^{9}$ Phytochemical Research Laboratory, Department of Pharmaceutical Chemistry, University of Dhaka, Dhaka, Bangladesh
\end{abstract}

Gymnema sylvestre is a plant included in Apocynaceae family and is located in many regions of Asia, Africa and Australia. This plant is widely used as a traditional therapy for different purposes. Even now it is being used as a dietary supplement due to its numerous therapeutic uses. It is known to have blood glucose lowering potential and, thus, is widely used in traditional and Ayurvedic systems of medicine. It renders glucose lowering activity due to the presence of phytochemicals, such as gurmarin, gymnemic acid as well as gymnemasaponins. Gymnema sylvestre is also known to have antioxidant, antibiotic, anti-inflammatory, antiviral, gastro and hepatoprotective, anticancer and lipid-lowering activities. This review discusses in details on different pharmacological and clinical potentials of Gymnema sylvestre and its chemical constituents associated with its therapeutic potentials.

Keywords: Gymnema sylvestre, phytomedicine, antidiabetic, herbal medicine, traditional medicine, complementary and alternative medicine, immunomodulating, lipid lowering

\section{INTRODUCTION}

Plants are a great concern for drug discovery exploration and a major source of our modern medicine. About $25 \%$ of modern medicines are derived from a plant source and merely $5-15 \%$ of plants have been investigated for their medicinal use (Gurnani et al., 2014). Nowadays, natural plants, herbal medicines, phytomedicines, and functional foods are extensively studied by scientists all over the world which resulted with the lucrative therapeutic potentials such as antidiabetic (Sarker, 2015; Shah et al., 2016; Rouhi et al., 2017; Chen et al., 2018), anticancer (Sheikh et al., 2017a; Sheikh et al., 2017b), immunomodulating (Goto et al., 2010; Sarker et al., 2011; Sarker et al., 2012a; Sarker et al., 2012b; Sarker and Gohda, 2013), antiobesity and lipid lowering (Kazemipoor et al., 2015; Sarker, 2015), anti-inflammatory (Imam et al., 2013) and anti-bacterial (Yasmin et al., 2009) activies. Among the potential medicinal plants, Gymnema sylvestre, belongs to the family of Apocynaceae, 
and is traditionally used for the treatment of various dieseases. It is a wild herb found in India, Africa, Australia, and China (Christopoulos et al., 2010). It is known as Meshashringi, Merasingi, Kavali, Kalikardori, Vakundi, Dhuleti, Mardashingi, Podapatri, Adigam, Cherukurinja, Sannagerasehambu, Chigengteng or Australian Cowplant, Waldschlinge in German, Periploca of the woods in English (Kanetkar et al., 2007). This plant is also recognized as 'Gurmur', due to having sugar lowering property (Tiwari et al., 2014). Gymnema sylvestre was considered as one of the major botanicals to treat diabetes in the Ayurvedic system of medicine and also is included in Indian Pharmacopoeia as an anti-diabetic plant (Singh et al., 2008). As it is useful against major diseases such as cardiovascular diseases, asthma, cancer, diabetes and obesity, different formulation of this plant is found in a number of preparations such as tea bags, health tablets, and food supplements. In various studies, Gymnema sylvestre is reported to be effective against arthritis, diuretic, anemia, osteoporosis, hypercholesterolemia, cardiopathy, asthma, constipation, microbial infections, indigestion, and as an antiinflammatory agent (Tiwari et al., 2014). Although this plant has been proven valuable through its numerous useful properties, not many studies especially clinical studies on this plant are available. We aim to extensively review the therapeutic potential and phytochemical compounds present in this plant based on the published reports so far.

\section{SEARCH STRATEGY AND TERMS USED}

A comprehensive, electronic search was conducted for studies published before April 2019 using PubMed, SCOPUS, Web of Science, EMBASE, Elsevier, ScienceDirect, Researchgate, Google, and Google Scholar databases. Keywords related to, 'Pharmacology', 'Antioxidant', 'Anti-diabetic', 'Anticancer', 'Immunomodulatory', 'Anti-arthritis', Weight loss', 'Lipid lowering', 'Antimicrobial', 'Anti-inflammatory', 'Hepatoprotective', 'Gastroprotective,' 'Traditional', 'Phytochemicals' combined with 'Gymnema sylvestre' were used.

\section{BOTANICAL DESCRIPTION AND TAXONOMY OF GYMNEMA SYLVESTRE}

Gymnema sylvestre (Retz.) R.Br. ex Sm. is a vulnerable and slow growing species. It appears as highly branched, woody and can climb up to the top of the tree that grows in the dry forests of central and southern India and in other regions of Asia ( $\mathrm{Wu}$ et al., 2012; Kapoor, 2017). This is a shrub of pubescent type which has young stems and branches (Kanetkar et al., 2007). Its root system is of tap root type (Najafi and Deokule, 2011). Stems are cylindrical, branched, hard, twining, internodes terete, 0.7$17.2 \mathrm{~cm}$ long and $2-10 \mathrm{~mm}$ in diameter (Najafi and Deokule, 2011; Pramanick, 2016). The leaves have distichous phyllotactic opposite arrangement pattern, are $2.5-6 \mathrm{~cm}$ long, usually ovate or elliptical and simple (Kanetkar et al., 2007). Leaves are acute or shortly acuminate, have petioles of 1 - to 2 -cm long, are smooth above, with a rounded base, a densely velvety pubescent beneath, and ciliate along margins, especially on the nerves. Venation is of transverse and reticulate type with a marginal vein (Kirtikar and Basu, 1975; Pramanick, 2016). Seeds are $1.3 \mathrm{~cm}$ long, flat with a thin marginal wing and narrowly ovoid-oblong (Chopra et al., 2002; Kirtikar and Basu, 1975). Flowers are small and yellow in color, in axillary and lateral umbel in cymes. Follicles are terete, lanceolate and of up to 3 inches in length (Kanetkar et al., 2007). Calyx is 5-lobed, ovate, obtuse, ciliated where corolla is campanulated, yellow, 5-lobed (Pramanick, 2016). Flowering of the plant occurs during August to March. Propagation through seed is difficult due to a low viability of seeds and, thus, plantation of root cuttings in June and July or plantation of terminal cuttings in February and March is done as an alternative approach (Kirtikar and Basu, 1975).

Gymnema sylvestre (Retz.) R.Br. ex Sm. is from Gymnema genus which belongs to Apocynaceae family. This genus has 49 other approved species which includes Gymnema acuminatum Wall., Gymnema brevifolium Benth., Gymnema chalmersii Schltr., Gymnema hirsutum Wight and Arn. etc. (The Plant List, 2013). The Taxonomy of the plant is presented in Table 1.

\section{TRADITIONAL USES}

Gymnema sylvestre is mentioned in Shushruta, an ancient book on medicine as a remedy for glycosuria and urinary disorder (Nadkarni, 1986). It is a therapeutic herb having multiple potentials as mentioned in folk medicine, Ayurveda, and Homeopathic systems of medicine (Kanetkar et al., 2007). Traditionally, it has been used to treat diabetes, malaria and snake bites as well as to treat diseases caused by phlegm and piles in the Ayurvedic system of medicine (Kirtikar and Basu, 1975; Singh et al., 2008). In Ayurveda, the plant is prescribed for the treatment of dyspepsia, constipation, jaundice, hemorrhoids, renal and vesicle calculi, cardiopathy, asthma, bronchitis, amenorrhea, and leucoderma (Sastry, 1994; Nadkarni, 1996; Anis et al., 2000; Mathew, 2004). Furthermore, different parts of the plant such as the roots, stem, and leaves have been used as cardiotonic, digestive, diuretic, laxative, stimulant, stomachic, and uterine tonic in traditional medicine systems (Mathew, 2004). Various parts of this plant are used by different tribes in India such as the Sahariya tribe of Madhya Pradesh, Junglee Irulas of Nilgiri hills, Kol tribe of Chhattisgarh, and the Nayaks of Karnataka, to treat mainly asthma, eye and gastric problems, parkinsonism, urinary

TABLE 1 | Taxonomy of Gymnema sylvestre (Kirtikar and Basu, 1987).

\begin{tabular}{ll}
\hline Kingdom & Plantae \\
\hline Subkingdom & Tracheobionta \\
Superdivision & Spermatophyta \\
Division & Magnoliophyta \\
Class & Magnoliopsida \\
Subclass & Asteridae \\
Order & Gentianales \\
Family & Apocynaceae \\
Sub-family & Asclepiadaceae \\
Genus & Gymnema \\
Species & Gymnema sylvestre (Retz.) \\
& R.Br. ex Sm.
\end{tabular}


problems, and diabetes (Chopra et al., 2002; Anis et al., 2000; Potawale et al., 2008).

\section{PHYTOCHEMISTRY OF GYMNEMA SYLVESTRE}

Stems of Gymnema sylvestre were investigated using chromatographic techniques and were found to have several therapeutically important chemical compounds such as stigmasterol and triterpenoid saponin. Stigmasterol compounds have multiple therapeutic potentials including antidiabetic, hypoglycemic, antioxidant, anticancer activities. Triterpenoid saponins also exhibited anti-tumor, anti-fungal, hepatoprotective and antidiabetic potential in several studies (Matsuda et al., 1997; Kaur et al., 2011; Garai, 2014; Liu et al., 2014). Gymnemic acids and gymnemasaponins are major chemical constituents of this plant and are classified as oleanane saponins. Oleanane and dammarane type of saponins are found in the leaves of Gymnema sylvestre (Khramov et al., 2008). The leaves of this plant also have saponins, anthraquinones, cardiac glycosides etc. (Patel, 2017). Moreover, this plant was also observed to have tannin, quinones, flavonoids, and phenols. (Senthilkumar, 2015). The phytochemical compounds found in the analysis of Gymnema sylvestre is listed in Table 2.

\section{IN VITRO AND IN VIVO PHARMACOLOGICAL ACTIVITY REPORTS ON GYMNEMA SYLVESTRE}

In vitro and In vivo investigation of the therapeutic importance of Gymnema sylvestre revealed multifarious pharmacological potentials including anti-cancer, immunosuppressive, gastroprotective, hypoglycemic, anti-inflammatory, anti-infectious, and most importantly anti-diabetic activities. The pharmacological activities of phytochemicals derived from Gymnema sylvestre have been presented in Figure 1 and its reports are summarized in Table 3.

\section{Antidiabetic Activity}

The most widely known effect of Gymnema sylvestre is antidiabetic activity. Ethanol extract of this plant is reported to reduce glucose level by $46 \%$ where the water extract reduced glucose level by $26 \%$ and methanol extract by $12 \%$ (Mcburney and Gent, 1978; Luo et al., 2006; Kosta and Tiwari, 2009; Shah et al., 2011; Shah et al., 2012). In dexamethasone-induced insulin resistance rats, aqueous extract of this plant was found to be improving the altered glucose, insulin and lipid profile (Kumar S, et al., 2015). Administration of this plant in a diabetic animal model resulted in reductions in the blood levels of insulin, protein, triglycerides, cholesterol, and glucose, as well as a reduction in body weight and was found to improve liver histopathology (Sujin, 2008). In another study where alloxan-induced diabetic rats were used, this plant extract significantly $(p<0.05)$ reduced fasting blood glucose level, total cholesterol, serum triglycerides and increase
HDL-cholesterol level and is also described to significantly alter $(p<0.05)$ the elevated level of urea, uric acid and creatinine levels in diabetic rats to nearly normal levels (Sathya et al., 2008; Mall et al., 2009). Gymnema sylvestre reduced the level of blood glucose levels after both acute and chronic administration of methanolic extract of this plant on Wister rats (Dholi and Raparla, 2014). In the case of Streptozotocin-induced diabetic rats, it has been shown that treatment using this plant significantly $(p<0.05)$ decreased the elevated blood glucose, ALT, AST, triglycerides, total cholesterol, LDL-cholesterol, and malondialdehyde, and significantly $(p<0.05)$ increased insulin, HDL-cholesterol, and erythrocyte superoxide dismutase levels in diabetic rats and also is capable of regenerating insulin producing $\beta$-cells (Aralelimath and Bhise, 2012; Shafey et al., 2013; Kumar et al., 2017; Ahmed et al., 2017). Gymnemic acids (a type of triterpene saponin compounds) are the class of active constituents isolated form Gymnema sylvestre. It was found that gymnemic acid IV given at a dose of $3.4 / 13.4 \mathrm{mg} / \mathrm{kg}$ adaministered for 6 hours decreased blood glucose levels by $14.0-60.0 \%$ as compared to glibenclamide. Also, gymnemic acid IV increased plasma insulin levels in STZdiabetic mice when administered at a concentration of $13.4 \mathrm{mg} /$ $\mathrm{kg}$ (Sugihara et al., 2000). In a study, oral administration of small concentrations $(0.2 \mathrm{~g} / \mathrm{kg})$ of this plant produced a reduction in the elevated levels of blood sugar induced by sucrose (Kang et al., 1990). However, Galletto et al. (2004) also informed an absence of anti-diabetic activity of Gymnema sylvestre in an alloxan treated animal model (Galletto et al., 2004).

\section{Mechanism of Action of Gymnema Sylvestre for Antidiabetic Activity}

Several mechanisms have been proposed to explain the antidiabetic activity of Gymnema sylvestre (Figure 2). Gymnemic acids can prevent absorption of sugar molecules by the intestine, which leads to a reduction in blood sugar levels (Tiwari et al., 2014). One of the constituents of Gymnema sylvestre is gymnemic acid which is a mixture of saponins (Yoshikawa et al., 1993). The atomic arrangement of gymnemic acid molecules is similar to that of glucose molecules and it blocks the receptor site for sugar in the intestines, preventing the absorption of sugar which reduces blood sugar level (Sahu et al., 1996). Rapid screening by Affinity UltrafiltrationHPLC-MS shows that it contains a-glucosidase inhibitors (Chen and Guo, 2017). It is reported to increase the activity of enzymes which are insulin dependent including hexokinase, glycogen synthetase, glyceraldehydes 3-phosphate dehydrogenase, and glucose 6-phosphate dehydrogenase, and to decrease the activity of insulin-independent enzymes such as glycogen phosphorylase, gluconeogenic enzymes, glucose 6-phosphatase, fructose 1,6- diphosphatase, and sorbitol dehydrogenase, which also increases phosphorylase activity. Gymnema sylvestre was also found to increase the secretion of insulin and the possible role in regenerating insulin as well as $\beta$-cell was suggested (Shanmugasundaram et al., 1990a; Nakamura et al., 1999; Aralelimath and Bhise, 2012). In a study, methanol extract of this plant showed increased effect on $\beta$-cell regeneration and was extrapolated that this plant 
TABLE 2 | Phytochemical constituents of Gymnema sylvestre.

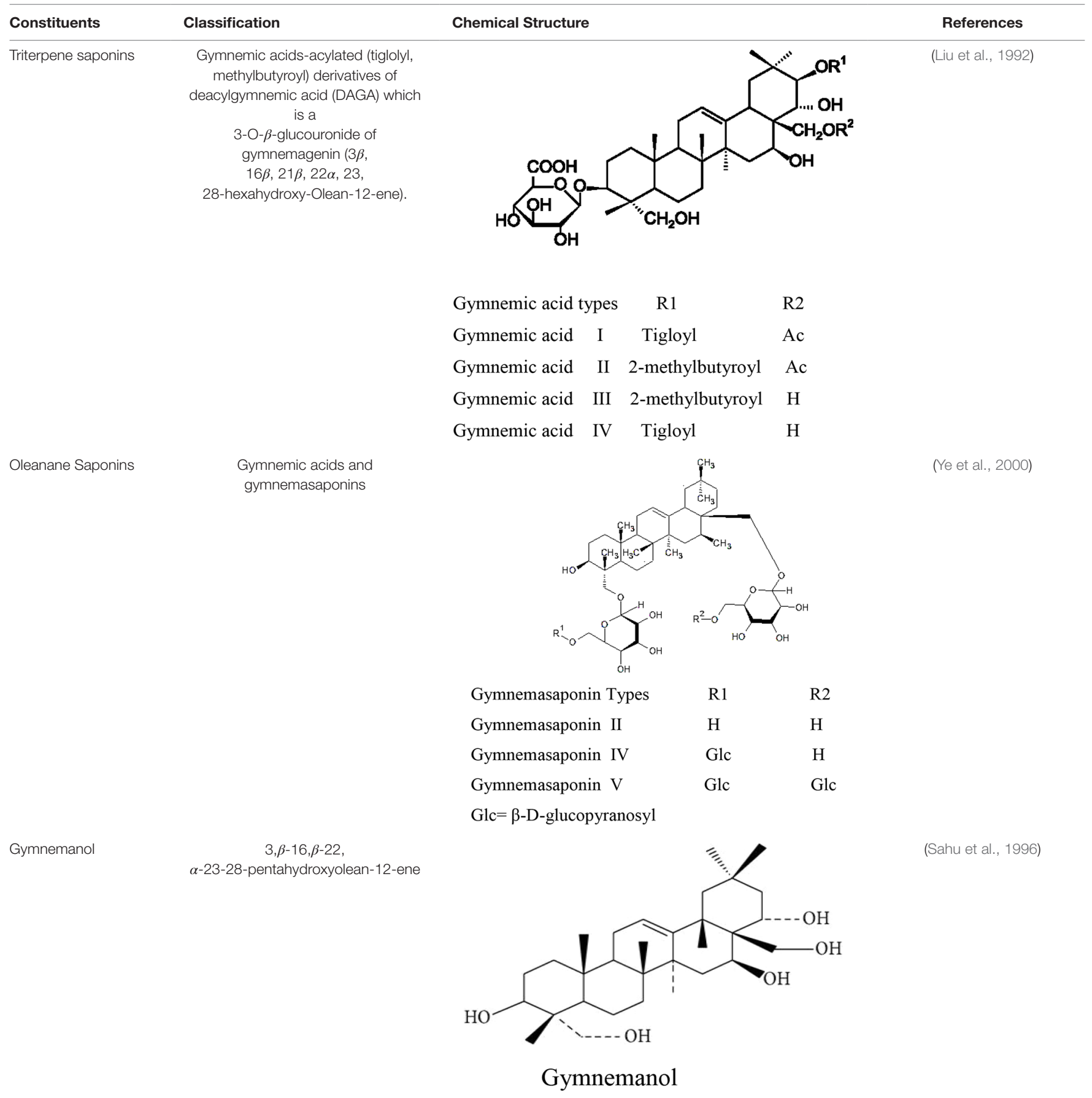

might be able to completely recover pancreatic-cells function and thus treating type I diabetes (Ahmed et al., 2010).

\section{Anticancer Activity}

Gymnema sylvestre was found to have anticancer activity in various investigations. Its constituent gymnemagenol (C30H50O4) showed positive anticancer activity against HeLa cells (Khanna, 2010). The ethanolic, ethyl and chloroform extract were tested for anticancer activity against A549 (human lung adenocarcinoma) and MCF7 (human breast carcinsoma) cell lines. Theses extract revealed anticancer activity with a similar IC50 value against MCF cell lines where in the case of A549, ethyl and chloroform extract were more active than the ethanol extract (Srikanth et al., 2010). Ethanolic extract of Gymnema sylvestre showed anticancer activity in A375 cells (human skin melanoma). It showed cytotoxic activity against 
TABLE 2 | Continued
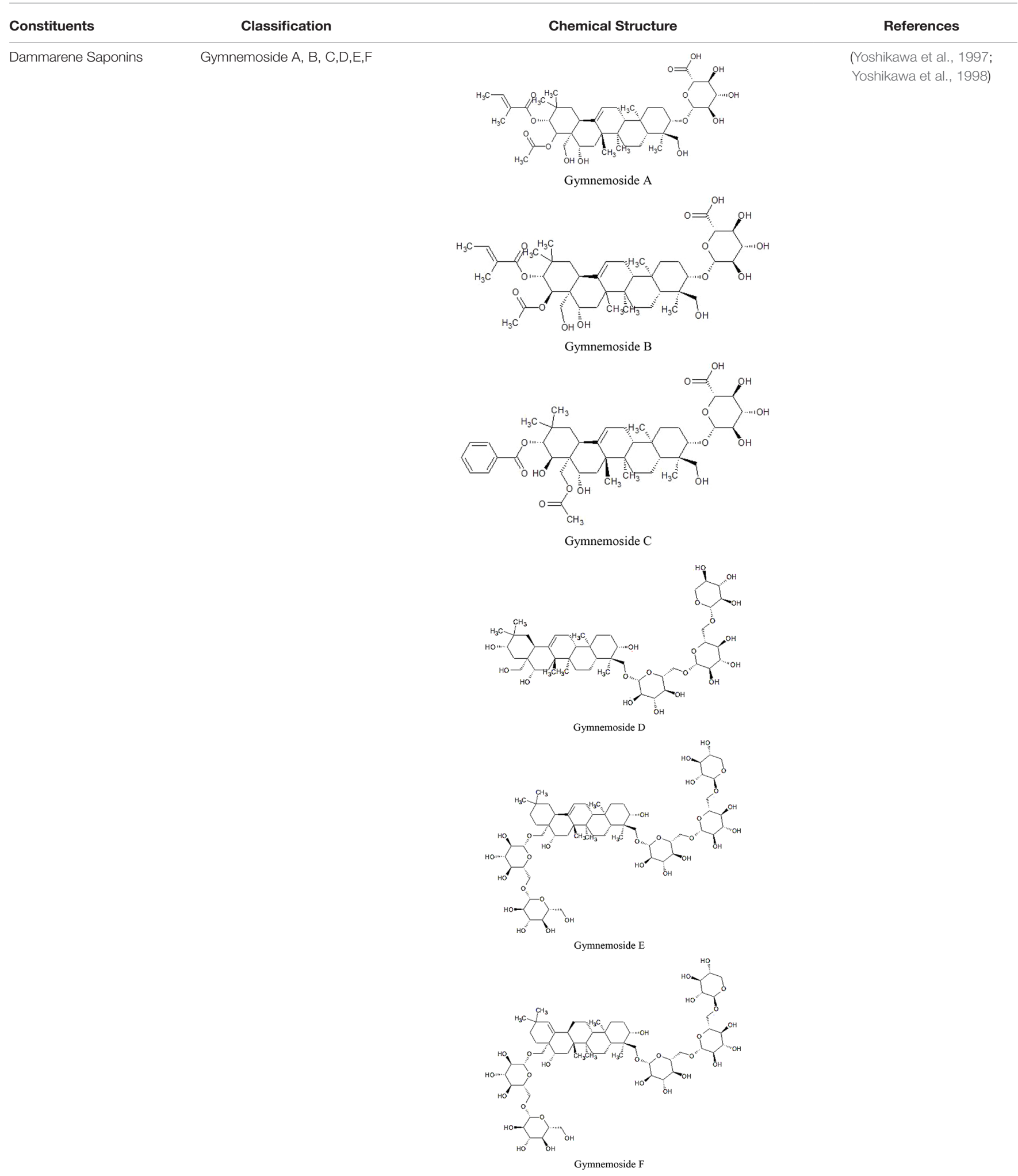
TABLE 2 | Continued

\section{Constituents}

Gymmestrogenin

Classification

Pentahydroxytriterpene

Gurmarin

Triterpenoid saponins Gymnemasin A

Gymnemasin B

Gymnemasin C

Gymnemasin D
A 35-Amino acid peptide with a molecular weight of 4209

3-O [ $\beta$-D-glucopyranosyl (1-3)- $\beta$-D-glucopyranosyl]-22-Otiglyol gymnemanol 3-O-[ $\beta$-D-glucopyranosyl-(1-3)- $\beta$-Dglucuro- nopyranosyl]Gymnemanol 3-O- $\beta$-D-glucuronopyranosyl-22-Otigloyl-gymnemanol 3-O- $\beta$-D-glucopyranosyl-gymnemanol
Chemical Structure<smiles>CC1(C)C[C@]2(C)C3=CCC4[C@](C)(CCC5[C@](C)(CO)C(O)CC[C@]45C)[C@@]3(C)C[C@H](O)[C@@]2(CO)C[C@H]1O</smiles>

$<1$ Glu- Gln- Cys- Val- 5Lys- Lys- Asp- Glu- Leu- 10Cys- IlePro-Tyr- Tyr- 15Leu- Asp- Cys- Cys- Glu- 20Pro- Leu- GluCys- Lys-25Lys- Val- Asn- Trp- Trp- 30Asp- His- Lys- Cys- Ile35Gly>.

(Glu = pyroglutamic-acid)

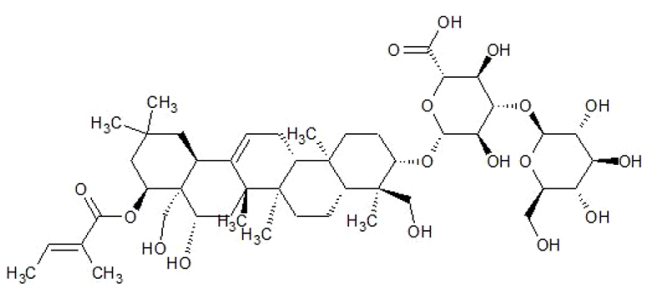

Gymnemasin A

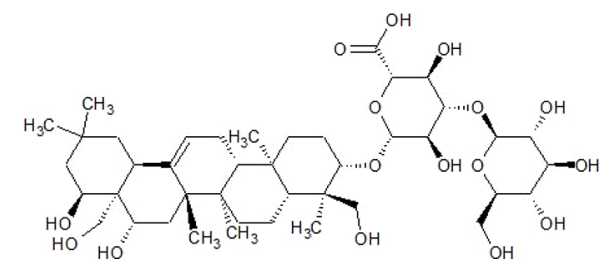

Gymnemasin B

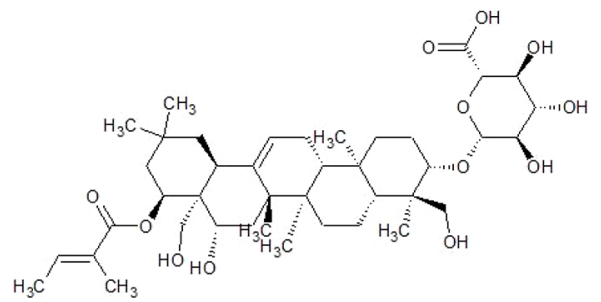

Gymnemasin C

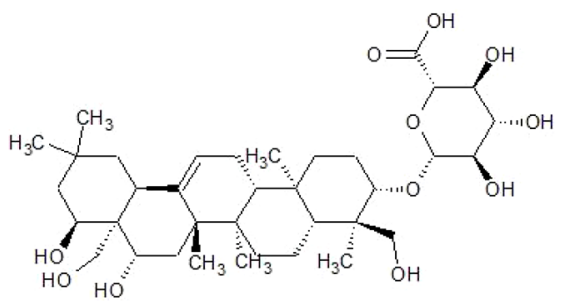

(J-GLOBAL-Japan Science and Technology Agency, n.d.a; J-GLOBAL-Japan Science and Technology Agency, n.d.b; J-GLOBAL-Japan Science and Technology Agency, n.d.c; J-GLOBAL-Japan Science and Technology Agency, n.d.d)

(Yoshikawa et al., 1998)

(Imoto et al., 1991) 
TABLE 2 | Continued

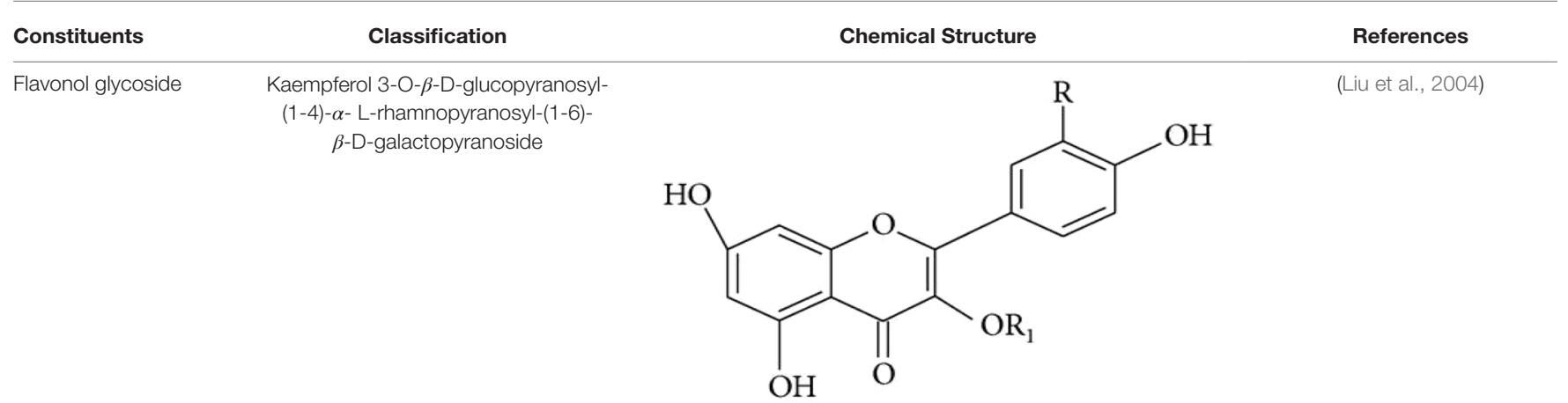

Sterols

Stigmasterol<smiles>CCC(/C=C(/C)CC1CCC2C1CCC1C2CC=C2CC(O)CCC21C)C(C)C</smiles>

(Potawale et al., 2008)

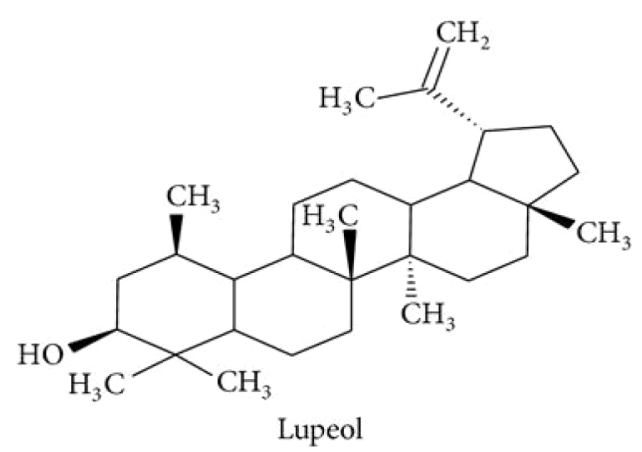

(Sinsheimer et al., 1970)

Lupeol

d-Quercitol<smiles>OC1CC(O)C(O)C(O)C1O</smiles>

Parabin<smiles>O=C(O)c1ccc(O)cc1</smiles>

(Sinsheimer et al., 1970)

Paraben 
TABLE 2 | Continued

Constituents

Quercitol

Conduritol A

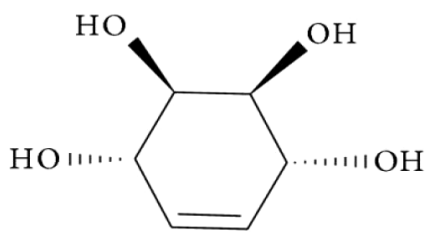

Conduritol A
References<smiles>O=c1cc(-c2ccc(O)cc2)oc2cc(O)cc(O)c12</smiles>

(Tiwari et al., 2014).
- Cytotoxic activity

- Antimicrobial activity

- Anti-cancer activity

- Antiinflammator $y$ activity

- Anti-viral activity
- Anti-tumor activity

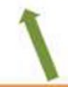

\section{Dammarene}

Saponins

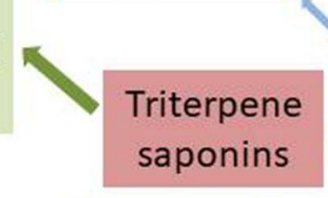

- Cytotoxic and antitumor activity

- Anti-diabetic activity

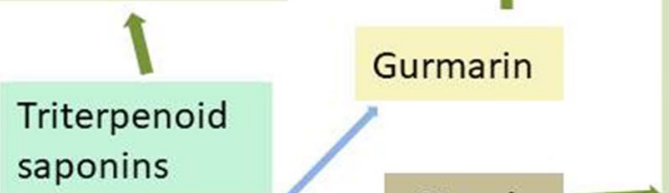

\section{Sterols}

\section{Triterpene $\beta$ -}

Amyrin related

glycosides saponins glycoside

\section{Quercitol}

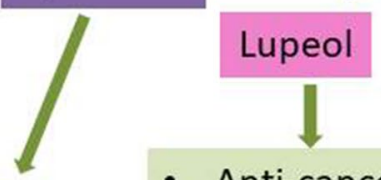

- Anti-cancer activity

- Anti-inflammatory activity

\section{Anthraquinones} activity activity
- Reduce cholesterol

- Anticancer activity

\section{- Antiviral} activity

- Anti-Inflammatory

- Antinociceptive 
TABLE 3 | Summary of Pharmacological Effects of Gymnema sylvestre.

\begin{tabular}{|c|c|c|c|c|}
\hline $\begin{array}{l}\text { Gymnema sylvestre } \\
\text { Extract }\end{array}$ & $\begin{array}{l}\text { Type of } \\
\text { study }\end{array}$ & Study Model & Activities & References \\
\hline \multirow[t]{4}{*}{ Water } & In vivo & $\begin{array}{l}\text { Alloxan induced diabetic and normal Male } \\
\text { Wister albino rats }\end{array}$ & Blood glucose level was reduced & $\begin{array}{l}\text { (Sathya et al., 2008; } \\
\text { Ahmed et al., 2010) }\end{array}$ \\
\hline & In vitro & & - Anti- oxidant activity & (Arun et al., 2014) \\
\hline & In vivo & Albino Rats & $\begin{array}{l}\text { - Anti-allergic } \\
\text { - Anti-stress } \\
\text { - Inhibition of aspirin-induced gastric } \\
\text { ulcers }\end{array}$ & \\
\hline & In vitro & $\begin{array}{l}\text { Staphylococcus aureus and Staphylococcus } \\
\text { epidermidis, } \\
\text { Escherichia coli, } \\
\text { Klebsiella pneumoniae 1, Klebsiella pneumoniae } \\
\text { 2, Pseudomonas aeruginosa, Salmonella } \\
\text { typhimurium 1, } \\
\text { Salmonella typhimurium 2, Shigella } \\
\text { Flexneri, Candida albicans, } \\
\text { Candida tropicalis, } \\
\text { Methicillin-resistant Staphylococcus } \\
\text { Aureus }\end{array}$ & $\begin{array}{l}\text { - Antimicrobial activity against } \\
\text { Pseudomonas aeruginosa, Candida } \\
\text { albicans, Klebsiella pneumoniae 1, } \\
\text { Pseudomonas aeruginosa, Salmonella } \\
\text { typhimurium 2, Escherichia coli, } \\
\text { Staphylococcus aureus, Methicillin- } \\
\text { resistant Staphylococcus aureus } \\
\text { - Enterococcus faecalis and } \\
\text { Staphylococcus epidermidis were } \\
\text { insensitive to the plant extract. }\end{array}$ & $\begin{array}{l}\text { (Arora and Sood, } \\
\text { 2017) }\end{array}$ \\
\hline Alcohol & In vivo & Wister Rats & $\begin{array}{l}\text { - Fat digestibility was decreased } \\
\text { - Excretion of neutral sterols and acid } \\
\text { steroids into feces was increased } \\
\text { - Decreased the total cholesterol and } \\
\text { triglyceride levels in serum } \\
\text { - The decrease in body weight } \\
\text { - Inhibition of fat accumulation }\end{array}$ & $\begin{array}{l}\text { (Shigematsu et al., } \\
\text { 2001a; Shigematsu } \\
\text { et al., 2001b) }\end{array}$ \\
\hline Acetone & - & $\begin{array}{l}\text { Culex } \\
\text { tritaeniorhynchus Giles (Diptera: Culicidae) }\end{array}$ & - Larvicidal Activity & $\begin{array}{l}\text { (Elumalai et al., } \\
\text { 2013) }\end{array}$ \\
\hline \multirow[t]{2}{*}{ Methanol } & - & $\begin{array}{l}\text { Culex } \\
\text { tritaeniorhynchus Giles (Diptera: Culicidae) }\end{array}$ & - Larvicidal Activity & $\begin{array}{l}\text { (Elumalai et al., } \\
\text { 2013) }\end{array}$ \\
\hline & In vivo & Wister rats & $\begin{array}{l}\text { - Reduced blood glucose level } \\
\text { - Reduced triglyceride, cholesterol level } \\
\text { - Lowered urea, creatinine level }\end{array}$ & $\begin{array}{l}\text { (Dholi and Raparla, } \\
\text { 2014) }\end{array}$ \\
\hline \multirow[t]{2}{*}{ Chloroform } & - & $\begin{array}{l}\text { Culex } \\
\text { tritaeniorhynchus Giles (Diptera: Culicidae) }\end{array}$ & - Larvicidal Activity & (Elumalai et al., 2013 \\
\hline & In vitro & $\begin{array}{l}\text { B. subtilis, S. epidermis, E. faecalis, S. aureus, } \\
\text { P. aeruginosa, E. cloacae; E. aerogene; E. coli, } \\
\text { S. typhimuriumand K. pneumoniae }\end{array}$ & $\begin{array}{l}\text { - Shown wide range of inhibitory activity } \\
\text { against Staphylococcus aureus and } \\
\text { Klebsiella pneumoniae }\end{array}$ & $\begin{array}{l}\text { (Chodisetti et al., } \\
\text { 2013) }\end{array}$ \\
\hline \multirow[t]{4}{*}{ OSA } & In vitro & $\begin{array}{l}\text { MIN6 mouse } \beta \text {-cell and human islets of } \\
\text { Langerhans }\end{array}$ & - Increased insulin secretion & (Liu et al., 2009) \\
\hline & In vivo & Insulin-resistant ob/ob mice & - Improved glucose-intolerant status & \multirow{3}{*}{$\begin{array}{l}\text { (Al-Romaiyan et al., } \\
\text { 2010) }\end{array}$} \\
\hline & In vitro & Isolated mouse islets & - Increased insulin secretion & \\
\hline & In vitro & Human Islets of Langerhans & - Increase in Insulin Secretion & \\
\hline
\end{tabular}


TABLE 3 | Continued

\begin{tabular}{|c|c|c|c|c|}
\hline $\begin{array}{l}\text { Gymnema sylvestre } \\
\text { Extract }\end{array}$ & Type of study & Study Model & Activities & References \\
\hline \multirow[t]{4}{*}{$\begin{array}{l}\text { Gymnemic Acids extracted } \\
\text { from Gymnema sylvestre }\end{array}$} & In vitro & Male Hartley Guinea-pigs & $\begin{array}{l}\text { - Suppressive effect on the } \mathrm{H}-65 \\
K_{+} \text {induced contraction of the ileal } \\
\text { longitudinal muscle }\end{array}$ & (Shimizu et al., 1997) \\
\hline & In vitro & Guinea-pigs and Wister rats & $\begin{array}{l}\text { - Suppression of glucose invoked } \\
\text { transmural potential difference increase } \\
\text { in the inverted intestines }\end{array}$ & \\
\hline & In vivo & Male Sprague-Dawley Strain Rats & - Suppression of Glucose level & \\
\hline & In vivo & Male rats of the Wistar-ST strain & $\begin{array}{l}\text { - Increased fecal cholesterol and } \\
\text { CA-derived bile acid excretion }\end{array}$ & $\begin{array}{l}\text { (Nakamura et al., } \\
\text { 1999) }\end{array}$ \\
\hline \multirow[t]{8}{*}{ Ethanol Extract } & In vivo & $\begin{array}{l}\text { Ulcerative } \\
\text { colitis induced Wister albino rats }\end{array}$ & $\begin{array}{l}\text { - Suppressed oxidative and inflammatory } \\
\text { response } \\
\text { - Protected colonic mucosal content }\end{array}$ & (Aleisa et al., 2014) \\
\hline & In vivo & Streptozotocin-induced diabetic Albino Rats & $\begin{array}{l}\text { - Establishes blood glucose homeostasis } \\
\text { - Brings glycoconjugate components to } \\
\text { near normal levels }\end{array}$ & $\begin{array}{l}\text { (Shanmugasundaram } \\
\text { et al., 1988) }\end{array}$ \\
\hline & In vitro & $\begin{array}{l}\text { Human skin melanoma cell line (A375) and } \\
\text { normal liver cell line (WRL-68) }\end{array}$ & - Apoptotic effect on A375 cells & $\begin{array}{l}\text { (Chakraborty et al., } \\
\text { 2013) }\end{array}$ \\
\hline & In vivo & Female ICR mice & $\begin{array}{l}\text { - Showed inhibitory effects on TPA- } \\
\text { induced inflammation }\end{array}$ & $\begin{array}{l}\text { (Yasukawa et al., } \\
\text { 2014) }\end{array}$ \\
\hline & In vivo & $\begin{array}{l}\text { Streptozotocin-induced diabetic Wistar albino } \\
\text { rats }\end{array}$ & $\begin{array}{l}\text { - Reduction in the pain threshold } \\
\text { - Reduction in body weight } \\
\text { - Mitigation of blood glucose levels and } \\
\text { increased insulin level } \\
\text { - Attenuated the elevated levels of } \\
\text { cytokines in the serum and sciatic } \\
\text { tissues }\end{array}$ & (Fatani et al., 2015) \\
\hline & In vitro & & - exhibited strong antioxidant activity & (Kang et al., 2012) \\
\hline & In vivo & $\begin{array}{l}\text { Streptozotocin induced diabetic Sprague- } \\
\text { Dawley male rats }\end{array}$ & $\begin{array}{l}\text { - Decreased the activity of glutathione } \\
\text { peroxidase in cytosolic liver } \\
\text { - Reduced glutamate pyruvate } \\
\text { transaminase in serum to normal levels }\end{array}$ & (Daisy et al., 2009) \\
\hline & In vivo & Streptozotocin-induced diabetic Wister rats & $\begin{array}{l}\text { - Showed hypoglycemic and } \\
\text { hypolipidemic activity }\end{array}$ & \\
\hline $\begin{array}{l}\text { Dihydroxy gymnemic } \\
\text { triacetate isolated from } \\
\text { Gymnema sylvestre }\end{array}$ & In vitro & Mouse pancreatic $\beta$-cell lines (MIN6) & $\begin{array}{l}\text { - Inhibited yeast } \alpha \text {-glucosidase, sucrase, } \\
\text { maltase, and pancreatic } \alpha \text {-amylase } \\
\text { - Increased insulin secretion } \\
\text { - Showed protection against } \mathrm{H}_{2} \mathrm{O}_{2} \\
\text { induced ROS generation }\end{array}$ & (Shenoy et al., 2018) \\
\hline $\begin{array}{l}\text { Isolated Triterpene } \\
\text { Glycoside } \\
\text { fraction from Gymnema } \\
\text { sylvestre }\end{array}$ & In vitro & Wister Rats & $\begin{array}{l}\text { - Inhibited Glucose-Stimulated Gastric } \\
\text { Inhibitory Peptide Secretion }\end{array}$ & (Fushiki et al., 1992) \\
\hline
\end{tabular}

A375 cell and antitumor activity in skin Papilloma model where, in the case of normal liver cells WRL-68, it showed no cytotoxic activity (Chakraborty et al., 2013). It was revealed to have significant $(p<0.0001)$ inhibitory effect against intestinal breast cancer resistance protein (BCRP) (Tamaki et al., 2010). In a study, the administration of flavonoids was found to be inhibiting BCRP and subsequently, improving multi-drug resistance of BCRP substrates that was induced by it (Imai et al., 2004). Thus, it can be suggested that inhibition of this protein by Gymnema sylvestre may improve the activity of BCRP substrates methotrexate, daunorubicin, topotecan, epirubicin, flavopiridol, and so on by increasing systemic availability and absorption (Mao, 2005). Ethanolic extract of this plant exhibited antiproliferative effects in mice with two-stage carcinogenesis with a 50\% inhibitory dose of 50-555 nmol/ear (Yasukawa et al., 2014). Polysaccharides (GSP11, GSP22, GSP33, GSP44 and GSP55) isolated from Gymnema sylvestre was reported to have anticancer activity by improving immunological function through increasing phagocytic function, enhanced serum hemolysin levels, 


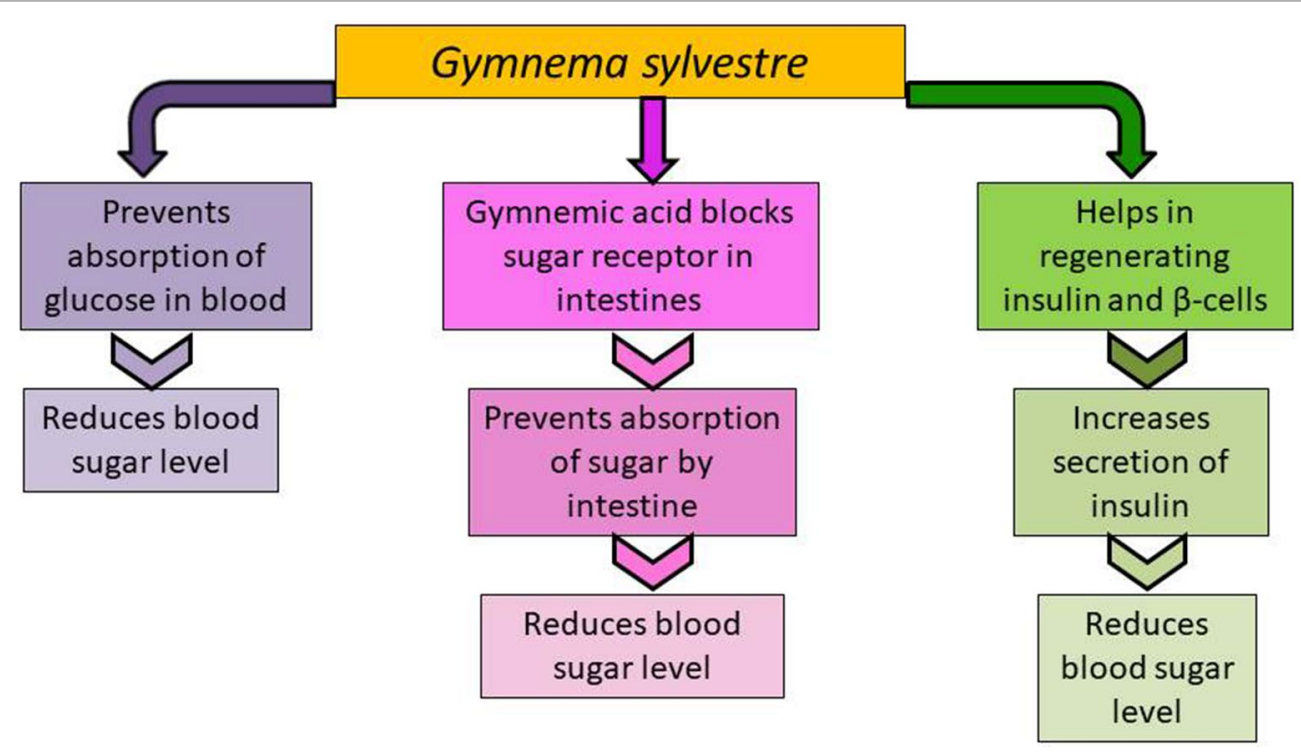

FIGURE 2 | Mechanism of glucose lowering activity by Gymnema sylvestre.

thymus, and spleen indexes. GSP11 and GSP33 showed inhibitory rates of $78.6 \%$ and $83.8 \%$, respectively, against U937 cells and GSP22 showed activity against SGC cells with an inhibitory rate of $78.2 \%$. (Wu et al., 2012). In another study, antitumor potential of this plant was observed when methanolic extract of Gymnema sylvestre was administered on Swiss albino mice where papillomagenesis was induced using carcinogen 7, 12 - dimethylbenz (a) anthracene (DMBA). Decreased tumor incidence, tumor burden and the cumulative number of papillomas were observed after the treatment with the plant extract (Agrawal et al., 2016).

\section{Lipid-Lowering Activity}

Gymnema sylvestre leaf extract was observed to possess very potent hypolipidaemic activity. In a study, Gymnema sylvestre leaf extract was administered to Wister female rats. These rats were introduced to hyperlipidemia by high-fat diet. It was detected that this extract significantly lowered the level of cholesterol $(p<0.01)$, low-density lipoprotein (LDL) $(p<0.01)$, and triglyceride $(p<0.01)$ as well as increased the level of highdensity lipoprotein (HDL) $(p<0.001)$ effectively (Singh et al., 2017). Furthermore, hydro-alcoholic leaf extract of Gymnema sylvestre was also observed to have lipid-lowering potential. In this study, rats were given high cholesterol for seven days and a higher level of cholesterol, triglyceride, LDL, and a lower level of HDL was observed. After seven days, these rats were treated with Gymnema sylvestre extract and it was reported to lower the elevated cholesterol, triglyceride, LDL level and increase the HDL level. It was suggested that this plant renders lipidlowering potential due to the presence of acidic constituents such as flavonoids, saponins, tannins etc. (Rachh et al., 2010; Dholi and Raparla, 2014). Similarly, in several other studies, it was reported to reduce triglyceride, cholesterol, very lowdensity lipoprotein (VLDL) and low-density lipoprotein (LDL) in diabetic rats (Bishayee and Chatterjee, 1994; Kumar et al., 2013).

\section{Antimicrobial Activity}

Different extracts and isolated bioactive compounds of Gymnema sylvestre were reported to have anti-microbial potential against several microorganisms. Methanolic extract of the leaves of this plant was reported to show antimicrobial activity against $E$. coli, B. cereus, $C$. albicans, and $C$. kefyr. The aqueous extract showed moderately anti-microbial activity against $S$. aureus, C. krusei, C. perfringens type-A and C. kefyr where the hexane extract showed activity against $S$. aureus, $B$. cereus, $S$. enterica, $H$. paragallinarum and C. perfringens type-A (David and Sudarsanam, 2013; Tahir et al., 2017). Both aqueous and ethanol extract is active against pathogenic Salmonella species (Salmonella typhi, S. Typhimurium, and S. paratyphi). Ethanolic, chloroform, and ethyl acetate extracts were reported to be active against $P$. vulgaris, $E$. coli, $P$. aeroginosa, K. pneumoniae, and $S$. aureus (Pasha et al., 2009; Paul and Jayapriya, 2009). Swami and Prabakaran (2012) observed that this plant was effective against several gram positive and negative bacteria such as $S$. aureus, E. Coli, K. pneumoniae and $P$. aeruginosa. In a study where antimicrobial activity was measured using a disk diffusion method, gymnemic acid, isolated from this plant, also showed antimicrobial activity against E. coli, V. cholera, S. mutans, S. aureus, A. niger and C. albicans with zone of inhibition of 8.65 $\mathrm{mm}, 6.00 \mathrm{~mm}, 7.12 \mathrm{~mm}, 9.25 \mathrm{~mm}, 6.43 \mathrm{~mm}$ and $8.60 \mathrm{~mm}$, respectively (Gupta and Singh, 2014). It has anti-microbial potential against a wide range of microorganisms including E. coli, P. aeruginosa, B. subtilis, E. hirae, M. luteus, S. aureus and C. albicans (Thanwar et al., 2016; Arora and Sood, 2017; Gunasekaran et al., 2019). Antibacterial activity of gymnemic acid, a triterpene saponin, isolated from Gymnema sylvestre 
was also studied against E. coli and B. cereus and it was found active against the microbes (Shivanna and Raveesha, 2009). Recently, antimicrobial properties of Gymnema sylvestre leaf extract have been enhanced using poly- $\varepsilon$-caprolactone nanofibers (Ramalingam et al., 2019) or by using $\mathrm{ZnO}$ nanoparticles (Karthikeyan et al., 2019). Gymnema sylvestre with $\mathrm{ZnO}$ nanoparticles was found to be effective against gram positive Staphylococcus aureus and Streptococcus pneumoniae bacteria and gram negative Klebsiella pneumoniae, Shigella dysenteriae, Escherichia coli, Pseudomonas aeruginosa and Proteus vulgaris bacterial strains (Karthikeyan et al., 2019). Using poly- $\varepsilon$-caprolactone nanofibers with this plant was potently active against methicillin-resistant Staphylococcus aureus, Staphylococcus aureus, Pseudomonas aeruginosa, Staphylococcus epidermidis and Escherichia coli (Ramalingam et al., 2019).

\section{Antioxidant Activity}

Ethanol extract of this plant revealed significant $(p<0.05)$ 1,1-diphenyl-2-picrylhydrazyl (DPPH) radical scavenging activity and showed better antioxidant potential than A. bilimbi and C. frutescens (Rahman et al., 2014). Anti-oxidant activity of Gymnema sylvestre against DPPH was also observed in an investigation by Rupanar et al. (2012). This plant was found to have better DPPH radical scavenging than butylated hydroxyl toluene (BHT) and in another study it was also found to reduce LDL oxidation (Ohmori et al., 2005; Rupanar et al., 2012). Recently, in another study, hydroxyl free radical scavenging activity and significant antioxidative potential of this plant against DPPH was reported where DPPH inhibition was at the level of $87.3 \%$ and hydroxyl free radical inhibition was 59.8\% (Gunasekaran et al., $2019)$. It was also found to have significant radical scavenging activity against ferric $(p<0.05)$, super oxide $(p<0.05)$ and also against hydrogen peroxide $(p<0.05)$ (Rachh et al., 2009). Gymnema sylvestre showed antioxidant activity in several conditions such as against high fat diets, hydrogen peroxide, nitric oxide, and superoxide radically induced oxidative stress in rats (Arun et al., 2014; Kishore and Singh, 2015; Chakrapani and Periandavan, 2018).

\section{Antiarthritic Activity}

Aqueous and petroleum extract of Gymnema sylvestre revealed significant $(p<0.01)$ antiarthritic activity (Malik et al., 2010). It was suggested that Gymnema sylvestre may have reduced the release of inflammatory mediators which is necessary to reduce bone destruction in anti-arthritic condition (Malik et al., 2010). In another study, ethanolic extract of the root of Gymnema sylvestre reduced carrageenan rat paw oedema significantly $(p<$ 0.01 ) and inhibited $39-75 \%$ of histamine induced rat paw oedema (Shankar and Rao, 2008)

\section{Immunomodulating Activity}

Methanolic leaf extract of Gymnema sylvestre (MLEGS) showed immunosuppressive activity in Swiss Albino mice when it was tested by performing hemagglutination antibody (HA) titer, delayed-type hypersensitivity (DTH) tests and flow cytometric techniques for the estimation of $\mathrm{B}$ lymphocytes (CD3 and
CD19) and Th2 cytokines (IL-2, IFN- $\gamma$ and IL-4). This plant significantly reduced primary and secondary antibody response and DTH response in a dose-related manner. At $200 \mathrm{mg} / \mathrm{kg}$ body weight, the maximal reductions occurred in the production of CD3, CD19, IL- 2, IFN- $\gamma$ and IL- 4 at the level of $31.59,32.12,29.51,32.45$ and $33.53 \%$, respectively (Ahirwal et al., 2015). However, it was also perceived that Gymnema sylvestre enhances the level of myeloid and lymphoid components of the immune system. Methanolic extract of this plant significantly increased $(p<0.05)$ the stimulation of Nitric oxide (NO) and Reactive Oxygen Species (ROS) by stimulation of macrophage activity and, also, significantly $(p<0.05)$ reduced nitroblue tetrazolium (Singh et al., 2015). Aqueous extract of Gymnema sylvestre also stimulated the phagocytic function of human neutrophils suggesting an immunostimulatory activity (Jitender et al., 2009). Ethanol extract of this plant was observed to improve immunosuppressed condition induced by cyclophosphamide in Albino Rats. In this study, the plant extract significantly improved haemagglutination titer, phagocytic activity and decreased paw edema $(p<0.01, p<0.05$ and $p<$ 0.05 respectively), when compared with cyclophosphamide treated control (Kar et al., 2019). In another study, potent immunostimulatory potential of the aqueous extract of this plant was observed (Gupta et al., 2009).

\section{Anti-Inflammatory Activity}

Methanoic extract of Gymnema sylvestre showed antiinflammatory activity in Wistar rats where carrageenaninduced inflammation was introduced in the rats. Methanolic extract of this plant reduced carrageenan-induced rat paw edema significantly ( $p<0.05$ ) (Kumar et al., 2012). In another study, aqueous extract of this plant displayed inhibitory potential against carrageenan-induced rat paw edema and peritoneal ascites in mice (Diwan et al., 1995). Furthermore, ethanolic extract of this plant was reported to show inhibitory effects against TPA-induced inflammation, with a $50 \%$ inhibitory dose of $50-555 \mathrm{nmol} / \mathrm{ear}$ where In vivo two-stage carcinogenesis was introduced in mice using 7,12-dimethylbenz[a]anthracene as an initiator and 12-O-tetradecanoyl phorbol-13-acetate (TPA) as a promoter (Yasukawa et al., 2014).

\section{Effect on Gastrointestinal Tract}

Methanolic extract of Gymnema sylvestre showed anti-ulcer activity in pylorus ligated Wister rat, forced swim stressinduced ulcer model as well as in rats where ulcer was induced by Indomethacin. It reduced the ulcer index significantly $(p<0.01)$ and also reduced free acidity, total acidity and gastric volume, and increased the $\mathrm{pH}$ of gastric juice. It was suggested that anti-ulcer activity was due to the presence of phytochemical constituents such as saponins, flavanoids, tannins, sterols, glycosides, alkaloids, resins, carbohydrates, proteins, triterpenoids (Swetha et al., 2012). A herbomineral formulation containing Gymnema sylvestre was found to improve impaired gastric emptying and intestinal transit associated with diabetes. In this study, Gymnema sylvestre containing formulation was found to significantly restore gastric emptying time 
and intestinal transit $(p<0.001$ and $p<0.001$ respectively), (Somani et al., 2013). However, Gymnema sylvestre was also shown to inhibit Glucose-Stimulated Gastric Inhibitory Peptide Secretion in Wister Rats significantly $(p<0.05)$ (Fushiki et al., 1992). Ethanolic extract of the leaves was described to improve mucosal injury induced by ethanol in Wister Albino rats. In this study it was observed that treatment of rats with this plant extract resulted in a significant depletion of stomach-wall mucus $(p<0.001)$, total proteins $(p<0.01)$, nucleic acids $(p<0.001)$, and non-protein sulfhydryl groups ( $p<0.001$ ) (Al-Rejaie et al., 2012). In a study, where gastric ulcer was induced in Swiss Albino male mice, aqueous extract of this plant was reported to show anti-ulcerative properties where it was observed that treatment with the plant extract exhibited significant $(p<0.05)$ protective activity against aspirin induced ulcer in rat models (Arun et al., 2014).

\section{Hepatoprotective Activity}

In an in-vitro investigation, hydro-alcoholic extract of Gymnema sylvestre was observed to render anti-hepatotoxic function in a dose-dependent manner in isolated rat hepatocytes where hepatotoxicity was induced using D - galactosamine. A significant increase in the level of ASAT, ALAT, ALP, total bilirubin and direct bilirubin $(p<0.001)$ was observed (Srividya et al., 2010). It was reported to lower urea and creatinine levels after acute and chronic administration of methanolic extract of this plant in Wister rats (Dholi and Raparla, 2014). In a study where methanolic poly herbal preparation containing this plant was used, it was observed that the preparation can reverse hepatotoxicity in Albino rats induced by paraffin and carbon tetrachloride (Yogi and Mishra, 2016).

\section{Effect on Body Weight}

Ethanol extract of this plant was found to reduce body weight in Wister rats (Shigematsu et al., 2001a). Similarly, when Streptozotocin-induced diabetic Albino rats were treated with ethanolic extract of Gymnema syvestre, a significant $(p<0.001)$ weight reduction was also observed (Fatani et al., 2015). However, in a different study, ethanol extract of this plant was reported to cause increase in the weight of the whole body, liver, pancreas in alloxan induced diabetic Wistar rats (Ahmed et al., 2010).

\section{Anticaries Activity}

The methanol extract of Gymnema sylvestre disclosed antimicrobial activity against Streptococcus mutans which is responsible for the formation of dental caries (Devi and Ramasubramaniaraja, 2010). Gymnema Acid from this plant can reduce glucan as well as plaque formation by Streptococcus mutants (Porchezhian and Dobriyal, 2003).

\section{CLINICAL STUDY REPORTS OF GYMNEMA SYLVESTRE}

Apart from various investigations on animal models, different extracts of this plant were tested on humans to inspect its therapeutic potential on the human body. Clinical investigations on Gymnema sylvestre revealed its potential to reduce body weight and glucose levels, triglyceride, LDL-c, total cholesterol and elevate the amount of insulin and C-peptide available in blood. A study conducted on 58 patients with type 2 diabetes mellitus for 90 days resulted in the reduction of fasting $(\mathrm{p}<$ 0.005 ) and post prandial blood glucose levels ( $p<0.001)$ along with a reduction of triglyceride $(p<0.05)$ (Table 4) (Kumar et al., 2010). In another study, where 64 individuals with type 1 diabetes were treated with Gymnema leaf extract for 6 to 30 months resulted with the reduction of plasma glucose level, reduced external insulin dose and significant reduction in HbA1c $(p<0.001)$ (Shanmugasundaram et al., 1990b). Significant $(p<0.05)$ reduction in blood glucose level was observed in another study where 32 human subjects with type-2 diabetes were administered with Gymnema sylvestre leaf powder in hard gelatin capsule for 30 days. Reduction in triglyceride, cholesterol and LDL level was also observed in this study (Li et al., 2015) (Table 4). The therapeutic potential of Gymnema sylvestre (GS) observed from clinical studies so far conducted has been summarized in Table 4 .

\section{TOXICOLOGICAL REPORTS ON GYMNEMA SYLVESTRE}

Toxicology study on Albino mice treated with Gymnema sylvestre showed LD50 level at $3990 \mathrm{mg} / \mathrm{kg}$ and the safety ratio for normal and diabetic mice was found to be 11.08 and 16.03 respectively. In this study, no behavioral, neurologic and autonomic adverse effects were observed (Chattopadhyay, 1999). Another study reported LD50 of ethanol and water extract of Gymnema sylvestre to be $375 \mathrm{mg} / \mathrm{kg}$ where mice were treated by intraperitoneal route with the plant extract (Bhakuni and Dhar, 1971). One case of drug-induced liver injury (DILI) was informed in the case of a patient who was treated with Gymnema sylvestre for diabetes mellitus (Shiyovich et al., 2010). It was stated that this plant can cause hypoglycemia in both diabetic and non-diabetic patient (Khare et al., 1983) and in the case of the diabetic animal model, one study reported persistent hypoglycemic effect even after the treatment with Gymnema sylvestre was stopped (Srivastava et al., 1986). However, no toxic effects were observed in a study where male and female Wistar rats were treated with Gymnema sylvestre for 52 weeks (Ogawa et al., 2004).

\section{USE OF GYMNEMA SYLVESTRE AS DIETARY SUPPLEMENT}

Concerning the use of extract of Gymnema sylvestre as a dietary supplement in Europe, the European Food Safety Agency recognizes the property of this plant which maintains normal sugar levels in organisms and in their conditions of use it must contain 400- $800 \mathrm{mg}$ of gymnema extract, equal to $100-200 \mathrm{mg}$ kgymnemic acid (EFSA Panel on Dietetic Products, Nutrition and Allergies (NDA), 2010). 
TABLE 4 | Summary of clinical study results on Gymnema sylvestre.

\begin{tabular}{|c|c|c|c|c|}
\hline Preparation of the plant given & Number of subjects & Duration & Therapeutic potential & Reference \\
\hline $\begin{array}{l}\text { OSA (Novel high molecular weight GS } \\
\text { preparation) }\end{array}$ & 11 & 60 days & $\begin{array}{l}\text { - Significant reduction in fasting and post- } \\
\text { prandial blood glucose level }(p<0.005 \\
\text { and } p<0.02 \text { respectively) } \\
\text { - Significantly increased level of insulin and } \\
\text { C-peptide in blood ( } p<0.05 \text { and } p< \\
0.001 \text {, respectively) }\end{array}$ & $\begin{array}{l}\text { (Al-Romaiyan et al., } \\
\text { 2010) }\end{array}$ \\
\hline Extract of leaves in capsule form & $\begin{array}{l}58 \text { human subjects with } \\
\text { type- } 2 \text { diabetes }\end{array}$ & 90 days & $\begin{array}{l}\text { - Reduction in hyperglycemia and } \\
\text { hypertriglyceridemia }(p<0.05) \\
\text { - } \text { Reduced fasting and post-prandial blood } \\
\text { glucose levels significantly }(p<0.005 \text { and } \\
p<0.001 \text {, respectively) } \\
\text { - Significantly increased HbA1c level ( } p< \\
0.001) \\
\text { - Significantly reduced insulin resistance } \\
(p<0.05)\end{array}$ & (Kumar et al., 2010) \\
\hline GS leaf powder in hard gelatin capsule & $\begin{array}{l}32 \text { human subjects with } \\
\text { type- } 2 \text { diabetes }\end{array}$ & 30 days & $\begin{array}{l}\text { - Significantly reduced glucose level }(p< \\
\text { 0.05) } \\
\text { - Reduced triglyceride, cholesterol and LDL } \\
\text { level }\end{array}$ & (Li et al., 2015) \\
\hline Aqueous GS leaf extract & 8 healthy participants & $90 \mathrm{~min}$ & $\begin{array}{l}\text { - Reduced oral sweet taste sensation } \\
\text { significantly }(p<0.05) \\
\text { - Reduced blood glucose level }\end{array}$ & (Kashima et al., 2017) \\
\hline Ethanol extract of GS leaves & 22 type 2 diabetic patient & $\begin{array}{l}18-20 \\
\text { months }\end{array}$ & $\begin{array}{l}\text { - Reduced glucose level significantly }(p< \\
0.001) \\
\text { - Elevated serum insulin in both the fasting } \\
\text { and post-prandial state }\end{array}$ & (Baskaran et al., 1990) \\
\hline Leaf extract of GS & $\begin{array}{l}64 \text { individuals with type } \\
1 \text { diabetes }\end{array}$ & $\begin{array}{l}6 \text { to } 30 \\
\text { months }\end{array}$ & $\begin{array}{l}\text { - HbA1c level was reduced significantly } \\
(p<0.001) \\
\text { - Reduced glucose level } \\
\text { - Reduced requirement of Insulin }\end{array}$ & $\begin{array}{l}\text { (Shanmugasundaram et } \\
\text { al., 1990b) }\end{array}$ \\
\hline $\begin{array}{l}\text { G. sylvestre (Swanson Premium G. } \\
\text { sylvestre leaf; Swanson Health } \\
\text { Products, Fargo, ND, USA) }\end{array}$ & 24 diabetic patients & 12 weeks & $\begin{array}{l}\text { - Reduction in body weight, body mass } \\
\text { index (BMI) significantly }(p<0.05 \text { and } p< \\
0.05 \text {, respectively) } \\
\text { - Decreased level of very low-density } \\
\text { lipoprotein (VLDL) significantly }(p<0.05)\end{array}$ & (Zuñiga et al., 2017) \\
\hline $\begin{array}{l}\text { Calcium-potassium salt of } \\
\text { (-)-hydroxycitric acid, niacin-bound } \\
\text { chromium and GS }\end{array}$ & 90 obese subjects & 8 weeks & - Reduced weight & (Preuss et al., 2005) \\
\hline $\begin{array}{l}\text { Drops of GS "Q" with } \\
1 / 4 \text { cup of water }\end{array}$ & 21 people type 2 diabetes & 6 months & - Controlled blood glucose level & (Kothe and Uppal, 1997) \\
\hline $\begin{array}{l}\text { Aqueous decoction of shade-dried } \\
\text { powdered leaves of GS }\end{array}$ & $\begin{array}{l}10 \text { healthy and } 6 \text { diabetic } \\
\text { adults }\end{array}$ & 10 days & - Reduced blood glucose level & (Khare et al., 1983) \\
\hline
\end{tabular}

Presently, there are considerable knowledge gaps for the risk assessment of G. sylvestre preparations and open questions for whether results obtained with one preparation can be extrapolated to another Gymnema preparation. Also, based on the lack of systematic data on dose and effect relationships, the available information was regarded as not being sufficient for the derivation of health-based guidance values for Gymnema or Gymnema preparations. Considering the uncertainties for the composition of different Gymnema preparations, potential herb-drug interactions and the concerns about glucose lowering or hypoglycaemic effects, the use of Gymnema-based food supplements in combination with (or as a substitute for) authorized antidiabetic drugs may be associated with risks when used without medical supervision (Marakis et al., 2018).

\section{SUMMARY AND FUTURE PERSPECTIVES}

Phytochemicals account for numerous pharmacological properties. They are observed to have anti-metastatic, anti-diabetic, hypoglycemic, anti-oxidant, hepatoprotective, anti-inflammation, anti-bacterial, anti-fungal, anti-viral etc. activities. Plants contain compounds such as flavonoids, alkaloids, and tannins that render these life-saving therapeutic activities. It has been reported that about $80 \%$ of people from developing countries rely on natural 
medicines for the treatment of diseases and their primary health concerns (Hamilton, 2004). However, despite having great demand and therapeutic uses only $10 \%$ of the plants have been investigated for their therapeutic potential (Kumar V. H, et al., 2015). Furthermore, some of these plants which could be a great source of biologically important novel phytoconstituents are on the verge of extinction due to unsustainable use, destruction of forests, and habitat destruction (Brower, 2008). One of these therapeutically important plants that contain significant biologically important phytochemicals is Gymnema sylvestre. It constitutes saponins, flavonol, glycosides, gymnemanol, gurmarin etc. These phytochemicals isolated from Gymnema sylvestre can provide pharmacological activities such as anti-diabetic, anti-oxidative, anti-metastatic, anti-inflammatory, lipid-lowering and several other properties.

However, this plant is also subject to unsustainable use. It is disappearing very fast due to overexploitation and extensive collection to meet the demand (Choudhury, 1988). Many unauthorized preparations of this plant are found in the local market. People are using this plant as a cheap substitution for

\section{REFERENCES}

Agrawal, R. C., Soni, S., Jain, N., Rajpoot, J., and Maheshwari, S. K. (2016). Chemopreventive effect of Gymnema sylvestre in Swiss albino mice. Int. J. Sci. Res. Publ. 6 (1), 78-83.

Ahirwal, L., Singh, S., Kumar, M. D., Bharti, V., Mehta, A., and Shukla, S. (2015). In vivo immunomodulatory effects of the methanolic leaf extract of Gymnema sylvestre in Swiss albino mice. Arch. Biol. Sci. 67 (2), 561-570. doi: 10.2298/ ABS141027018A

Ahmed, A. B., Rao, A., and Rao, M. (2010). In vitro callus and in vivo leaf extract of Gymnema sylvestre stimulate $\beta$-cells regeneration and anti-diabetic activity in Wistar rats. Phytomedicine 17 (13), 1033-1039. doi: 10.1016/j. phymed.2010.03.019

Ahmed, S. K., Cheekavolu, C., Alasyam, N., and Sunil, M. (2017). Evaluation of hypoglycemic property of gurmar (Gymnema sylvestre) leaves methanolic extract (GSLME) in streptozocin (STZ) induced Diabetic Albino Rats. J. Med. Sci. Clin. Res. 5(12), 31753-31760. doi: 10.18535/jmscr/v5i12.78

Aleisa, A. M., Al-Rejaie, S. S., Abuohashish, H. M., Ola, M. S., Parmar, M. Y., and Ahmed, M. M. (2014). Pretreatment of Gymnema sylvestre revealed the protection against acetic acid- induced ulcerative colitis in rats. BMC Complement Altern. Med. 14 (49). doi: 10.1186/1472-6882-14-49

Al-Rejaie, S. S., Abuohashish, H. M., Ahmed, M. M., Aleisa, A. M., and Alkhamees, O. (2012). Possible biochemical effects following inhibition of ethanol-induced gastric mucosa damage by Gymnema sylvestre in male Wistar albino rats. Pharm. Biol. 50 (12), 1542-1550. doi: 10.3109/13880209.2012.694894

Al-Romaiyan, A., Liu, B., Asare-Anane, H., Maity, C. R., Chatterjee, S. K., Koley, N., et al. (2010). A novel Gymnema sylvestre extract stimulates insulin secretion from human islets In vivo and In vitro. Phytother. Res. 24 (9), 1370-1376. doi: $10.1002 /$ ptr.3125

Anis, M., Sharma, M. P., and Iqbal, M. (2000). Herbal ethnomedicine of the Gwalior forest division in Madhya Pradesh, India. Pharm. Biol. 38 (4), 241253. doi: 10.1076/1388-0209(200009)3841-AFT241

Aralelimath, V. R., and Bhise, S. B. (2012). Anti-diabetic effects of Gymnema sylvestre extract on streptozotocin induced diabetic rats and possible b-cell protective and regenerative evaluations. Dig. J. Nanomater. Bios. 7 (1), 135-142.

Arora, D. S., and Sood, H. (2017). In vitro antimicrobial potential of extracts and phytoconstituents from Gymnema sylvestre R.Br. leaves and their biosafety evaluation. AMB Express 7 (1), 115. doi: 10.1186/s13568-017-0416-z

Arun, L. B., Arunachalam, A. M., Arunachalam, K. D., Annamalai, S. K., and Kumar, K. A. (2014). In vivo anti-ulcer, anti-stress, anti-allergic, and functional properties of Gymnemic Acid Isolated from Gymnema sylvestre R Br. BMC Complement Altern. Med. 14 (70). doi: 10.1186/1472-6882-14-70 their anti-diabetic medicine without any knowledge of what part of the plant to be used which results in unnecessary destruction the whole plant. Thus, this plant is being wasted without being used up to their maximum potential. In order to prevent the waste of this plant, legal production of medicinal preparation from the plant should be ensured and sustainable use of this plant should be closely monitored. In addition to these, people should be also made aware of the proper use of the plant so that they can get maximum benefit from this plant.

\section{AUTHOR CONTRIBUTIONS}

MMRS conceived the concept. FK and MMRS wrote the initial draft and revised the manuscript. LCM, INM, CZ and MAR critically revised the manuscript. BYS and HFT significantly contributed to review the manuscript in reply to reviewers; FK, MMRS, LCM, INM, CZ, BYS, HFT and MAR finalized the manuscript. All authors read and approved the manuscript.

Baskaran, K., Ahamath, B. K., Shanmugasundaram, K. R., and Shanmugasundaram, E. R. B. (1990). Antidiabetic effect of a leaf extract from Gymnema sylvestre in non-insulin-dependent diabetes mellitus patients. J. Ethnopharmacol. 30 (3), 295-305. doi: 10.1016/0378-8741(90)90108-6

Bhakuni, D. S., and Dhar, M. L. (1971). Screening of Indian plants for biological activity: Part III. Indian J. Exp. Biol. 9, 91-102.

Bishayee, A., and Chatterjee, M. (1994). Hypolipidaemic and antiatherosclerotic effects of oral Gymnema sylvestre R. Br. Leaf extract in albino rats fed on a high fat diet. Phytother. Res. 8 (2), 118-120. doi: 10.1002/ptr.2650080216

Brower, V. (2008). Back to Nature: Extinction of Medicinal Plants Threatens Drug Discovery. J. Natl. Cancer. Inst. 100 (12), 838-839. doi: 10.1093/jnci/ djn 199

Chakraborty, D., Ghosh, S., Bishayee, K., Mukherjee, A., Sikdar, S., and KhudaBukhsh, A. R. (2013). Antihyperglycemic Drug Gymnema sylvestre Also Shows Anticancer Potentials in Human Melanoma A375 Cells via Reactive Oxygen Species Generation and Mitochondria-Dependent Caspase Pathway. Integr. Cancer. Ther. 12 (5), 433-441. doi: 10.1177/1534735413485419

Chakrapani, L. N., and Periandavan, K. (2018). Protective role of gymnemic acid in curbing high fat diet and high fructose induced pancreatic oxidative stress mediated type-2 diabetes in wistar rats. Int. J. Pharm. Sci. Res. 9 (5), 2130-2139. doi: 10.13040/IJPSR.0975-8232.9(5).2130-39

Chattopadhyay, R. (1999). A comparative evaluation of some blood sugar lowering agents of plant origin. J. Ethnopharmacol. 67 (3), 367-372. doi: 10.1016/ S0378-8741(99)00095-1

Chen, G., and Guo, M. (2017). Rapid Screening for $\alpha$-Glucosidase Inhibitors from Gymnema sylvestre by Affinity Ultrafiltration-HPLC-MS. Front. Pharmacol. 8, 228. doi: 10.3389/fphar.2017.00228

Chen, Y., Liu, Y., Sarker, M. M. R., Yan, X., Yang, C., Zhao, L., et al. (2018). Structural characterization and antidiabetic potential of a novel heteropolysaccharide from Grifola frondosa via IRS1/PI3K-JNK signaling pathways. Carbohyd. Polym. 198, 452-461. doi: 10.1016/j.carbpol.2018.06.077

Chodisetti, B., Rao, K., and Giri, A. (2013). Phytochemical analysis of Gymnema sylvestre and evaluation of its antimicrobial activity. Nat. Prod. Res. 27 (6), 583 587. doi: 10.1080/14786419.2012.676548

Chopra, R. N., Nayar, S. L., and Chopra, I. C. (2002). Glossary of Indian medicinal plants. National Institute of Science Communication and Information Resources, New Delhi, India.

Choudhury, B. P. (1988). "Assessment and conservation of medicinal plants of Bhubaneswar and its neighbourhood," in Proc. Indigenous medicinal plants Symp (New Delhi: Today \& Tomorrow's Printers \& Publishers), 211-219.

Christopoulos, M. V., Rouskas, D., Tsantili, E., and Bebeli, P. J. (2010). Germplasm diversity and genetic relationships among walnut (Juglans regia L.) cultivars 
and Greek local selections revealed by Inter-Simple Sequence Repeat (ISSR) markers. Sci. Hort. 125 (4), 584-592. doi: 10.1016/j.scienta.2010.05.006

Daisy, P., Eliza, J., and Farook, K. A. (2009). A novel dihydroxy gymnemic triacetate isolated from Gymnema sylvestre possessing normoglycemic and hypolipidemic activity on STZ-induced diabetic rats. J. Ethnopharmacol. 126 (2), 339-344. doi: 10.1016/j.jep.2009.08.018

David, B. C., and Sudarsanam, G. (2013). Antimicrobial activity of Gymnema sylvestre (Asclepiadaceae). J. Acute. Dis. 2 (3), 222-225. doi: 10.1016/ S2221-6189(13)60131-6

Devi, B. P., and Ramasubramaniaraja, R. (2010). Pharmacognostical and antimicrobial screening of Gymnema sylvestre R.Br, and evaluation of Gurmar herbal tooth paste and powder, composed of Gymnema sylvestre R.Br, extracts in dental caries. Int. J. Pharma. Bio. Sci. 1, 1-16.

Dholi, S. K., and Raparla, R. K. (2014). In vivo anti-diabetic evaluation of gymnemic acid in streptozotocin induced rats. J. Pharm. Innov. 3 (7), 82-86.

Diwan, P. V., Margaret, I., and Ramakrishna, S. (1995). Influence of Gymnema sylvestre on inflammation. Inflammopharmacol. 3 (3), 271-277. doi: 10.1007/ BF02659124

EFSA Panel on Dietetic Products, Nutrition and Allergies (NDA). (2010). Scientific Opinion on the substantiation of health claims related to various food(s)/food constituent(s) claiming maintenance of normal blood glucose concentrations. EFSA Journal 8 (2), 149. doi: 10.2903/j.efsa.2010.1490

Elumalai, K., Dhanasekaran, S., and Krishnappa, K. (2013). Larvicidal activity of Saponin isolated from Gymnema sylvestre $\mathrm{R}$. Br. (Asclepiadaceae) against Japanese Encephalitis vector, Culex tritaeniorhynchus Giles (Diptera: Culicidae). Eur. Rev. Med. Pharmacol. Sci. 17 (10), 1404-1410.

Fatani, A. J., Al-Rejaie, S. S., Abuohashish, H. M., Al-Assaf, A., Parmar, M. Y., Ola, M. S., et al. (2015). Neuroprotective effects of Gymnema sylvestre on streptozotocin-induced diabetic neuropathy in rats. Exp. Ther. Med. 9 (5), 1670-1678. doi: 10.3892/etm.2015.2305

Fushiki, T., Kojima, A., Imoto, T., Inoue, K., and Sugimoto, E. (1992). An Extract of Gymnema sylvestre Leaves and Purified Gymnemic Acid Inhibits GlucoseStimulated Gastric Inhibitory Peptide Secretion in Rats. J. Nutr. 122 (12), 23672373. doi: $10.1093 / \mathrm{jn} / 122.12 .2367$

Galletto, R., Siqueira, V. L., Ferreira, E. B., Oliveira, A. J., and Bazotte, R. B. (2004). Absence of antidiabetic and hypolipidemic effect of Gymnema sylvestre in nondiabetic and alloxan-diabetic rats. Braz. Arch. Biol. Technol. 47 (4), 545-551. doi: 10.1590/S1516-89132004000400007

Garai, S. (2014). Triterpenoid saponins. Nat. Prod. Chem. Res. 2 (6), 1000148. doi: $10.4172 / 2329-6836.1000148$

Goto, T., Sarker, M. M. R., Zhong, M., Tanaka, S., and Gohda, E. (2010). Enhancement of immunoglobulin $\mathrm{M}$ production in $\mathrm{B}$ cells by the extract of red bell pepper. J. Health Sci. 56 (3), 304-309. doi: 10.1248/jhs.56.304

Gunasekaran, V., Srinivasan, S., and Rani, S. S. (2019). Potential antioxidant and antimicrobial activity of Gymnema sylvestre related to diabetes. J. Med. Plants. 7 (2), 05-11.

Gupta, P., and Singh, P. (2014). Antimicrobial activity of Gymnemic acid on pathogens- Gymnema sylvestre R.Br. Int. J. Curr. Microbiol. App. Sc. 3 (5), 40-45.

Gupta, S. P., Pramanik, S., Tiwari, O., Thacker, N., Pande, M., and Upmanyu, N. (2009). Immunomodulatory Activity of Gymnema sylvestre Leaves. Internet J. Pharmacol. 8 (2). Available online: http://ispub.com/IJPHARM/8/2/8383. doi: $10.5580 / 14$ ed

Gurnani, N., Mehta, D., Gupta, M., and Mehta, B. K. (2014). Natural products: Source of potential drugs. Afr. J. Basic. Appl. Sci. 6, 171-186. doi: 10.5829/idosi. ajbas.2014.6.6.21983

Hamilton, A. C. (2004). Medicinal plants, conservation and livelihoods. Biodivers. Conserv. 13 (8), 1477-1517. doi: 10.1023/B:BIOC.0000021333.23413.42

Imai, Y., Tsukahara, S., Asada, S., and Sugimoto, Y. (2004). Phytoestrogens/ flavonoids reverse breast cancer resistance protein/ABCG2-mediated multidrug resistance. Cancer Res. 64 (12), 4346-4352. doi: 10.1158/0008-5472. CAN-04-0078

Imam, H., Mahbub, N. U., Khan, M. F., Hana, H. K., and Sarker, M. M. R. (2013). Alpha Amylase Enzyme Inhibitory and Anti-inflammatory Effect of Lawsonia inermis. Pak. J. Biol. Sci. 16 (23), 1796-1800. doi: 10.3923/ pjbs.2013.1796.1800

Imoto, T., Miyasaka, A., Ishima, R., and Akasaka, K. (1991). A novel peptide isolated from the leaves of Gymnema sylvestre-I. Characterization and its suppressive effect on the neural responses to sweet taste stimuli in the rat. Comp. Biochem. Physiol. A. Mol. Integr. Physiol. 100 (2), 309-314. doi: 10.1016/0300-9629(91)90475-R

J-GLOBAL-Japan Science and Technology Agency. (n.d.a). Gymnemasin A, J-GLOBAL ID: 200907028621377193,Nikkaji number: J708.815I. Retrieved from https://jglobal.jst.go.jp/en/detail?JGLOBAL_ID=200907028621377193\&q $=$ Gymnemasin $A \& t=0$ (accessed 3rd August 2019).

J-GLOBAL-Japan Science and Technology Agency. (n.d.b). Gymnemasin B, J-GLOBAL ID: 200907070830782735,Nikkaji number:J708.816G. Retrieved from https://jglobal.jst.go.jp/en/detail?JGLOBAL_ID=200907070830782735\&rel=1\# \%7B\%22category\%22\%3A\%220\%22\%2C\%22keyword\%22\%3A\%22Gymnema sin\%20\%22\%7D (accessed 3rd August 2019).

J-GLOBAL-Japan Science and Technology Agency. (n.d.c). Gymnemasin C, J-GLOBAL ID: 200907030904250402,Nikkaji number: J708.817E. Retrieved from https://jglobal.jst.go.jp/en/detail?JGLOBAL_ID=200907030904250402\& rel=1\#\%7B\%22category\%22\%3A\%220\%22\%2C\%22keyword\%22\%3A\%22Gy mnemasin\%20\%22\%7D (accessed 3rd August 2019).

J-GLOBAL-Japan Science and Technology Agency. (n.d.d). Gymnemasin D, -GLOBAL ID: 200907058480629513,Nikkaji number: J708.818C. Retrieved from https://jglobal.jst.go.jp/en/detail?JGLOBAL_ID=200907058480629513\& rel $=1 \# \% 7 \mathrm{~B} \% 22$ category $\% 22 \% 3 \mathrm{~A} \% 220 \% 22 \% 2 \mathrm{C} \% 22$ keyword $\% 22 \% 3 \mathrm{~A} \% 22 \mathrm{~Gy}$ mnemasin\%20\%22\%7D (accessed 3rd August 2019).

Jitender, K. M., Manvi, F. V., Nanjwade, B. K., Alagawadi, K. R., and Sanjiv, S. (2009). Immuno-modulatory activity of Gymnema sylvestre leaves extract on In vitro human neutrophils. J. Pharmacy Res. 2 (8), 1284-1286.

Kanetkar, P., Singhal, R., and Kamat, M. (2007). Gymnema sylvestre: A Memoir. J. Clin. Biochem. Nutr. 41 (2), 77-81. doi: 10.3164/jcbn.2007010

Kang, J. S., Koh, H. C., and Suh, T. K. (1990). Effect of gymnemic acid on the elevation of blood glucose concentration induced with oral sucrose in streptozotocin-diabetic rats. Hanyang Uidae Haksulchi 10 (1), 587-601.

Kang, M., Lee, M. S., Choi, M., Min, K., and Shibamoto, T. (2012). Hypoglycemic Activity of Gymnema sylvestre extracts on oxidative stress and antioxidant status in diabetic rats. J. Agric. Food. Chem. 60 (10), 2517-2524. doi: 10.1021/jf205086b

Kapoor, L. D. (2017). CRC Handbook of Ayurvedic Medicinal Plants. S.l. (Boca Raton, Florida, USA: CRC Press). doi: 10.1201/9780203719473

Kar, P. P., Rath, B., Ramani, Y. R., and Maharana, C. S. (2019). Amelioration of Cyclophosphamide induced immunosupression by the hydro-alcoholic extract of Gymnema sylvestre leaves in albino rats. Biomed. Pharmacol. J. 11 (1), 251258. doi: $10.13005 / \mathrm{bpj} / 1635$

Karthikeyan, M., Ahamed, A. J., Karthikeyan, C., and Kumar, P. V. (2019). Enhancement of antibacterial and anticancer properties of pure and REM doped $\mathrm{ZnO}$ nanoparticles synthesized using Gymnema sylvestre leaves extract. SN Appl. Sci. 1 (4), 355. doi: 10.1007/s42452-019-0375-x

Kashima, H., Eguchi, K., Miyamoto, K., Fujimoto, M., Endo, M. Y., AsoSomeya, N., et al. (2017). Suppression of Oral Sweet Taste Sensation with Gymnema sylvestre Affects Postprandial Gastrointestinal Blood Flow and Gastric Emptying in Humans. Chem. Senses 42 (4), 295-302. doi: 10.1093/ chemse/bjw126

Kaur, N., Chaudhary, J., Jain, A., and Kishore, L. (2011). Stigmasterol: a comprehensive review. Int. J. Pharm. Sci. Res. 2 (9), 2259-2265.

Kazemipoor, M., Cordell, G. A., Sarker, M. M. R., Radzi, C. W. J. B. W. M., Hajifaraji, M., and En Kiat, P. (2015). Alternative treatments for weight loss: Safety/risks and effectiveness of anti-obesity medicinal plants. Int. J. Food Prop. 18 (9), 1942-1963. doi: 10.1080/10942912.2014.933350

Khanna, G. (2010). Non-proliferative activity of saponins isolated from the leaves of Gymnema sylvestre and Eclipta prostrata on HepG2 cells-In vitro study. Int. J. Pharm. Sci. Res. 1 (8), 38-42. doi: 10.13040/IJPSR.0975-8232

Khare, A. K., Tondon, R. N., and Tewari, J. P. (1983). Hypoglycaemic activity of an indigenous drug (Gymnema sylvestre, "Gurmar") in normal and diabetic persons. Indian J. Physiol. Pharm. 27, 257-258.

Khramov, V. A., Spasov, A. A., and Samokhina, M. P. (2008). Chemical composition of dry extracts of Gymnema sylvestre leaves. Pharm. Chem. J. 42 (1), 30-32. doi: 10.1007/s11094-008-0051-8

Kirtikar, K. R., and Basu, B. D. (1975). "Indian medicinal plants, vol. III," in Periodical Experts D-42 (Vivek Vihar Delhi).

Kirtikar, K. R., and Basu, B. D. (1987). Indian Medicinal Plants. Lalit Mohan Basu, Allahabad. Jayyd Press, New Delhi, India, 2, 146.

Kishore, L., and Singh, R. (2015). Protective effect of Gymnema sylvestre L. against advanced glycation end-product, sorbitol accumulation and aldose reductase 
activity in Homoeopathic Formulation. Indian J. Res. Homoeopathy 9 (4), 240-248. doi: 10.4103/0974-7168.172866

Kosta, S., and Tiwari, A. (2009). Screening and assessment of anti-diabetic and reactive oxygen scavenging (ros), effects of herbs in streptozotacin induced mice. Pharmacol. online 3, 695-704.

Kothe, A., and Uppal, R. (1997). Antidiabetic effects of Gymnema sylvestre in NIDDM - a short study. Indian J. Homeopath. Med. 32, 61-62.

Kumar, A. R., Rathinam, K. S., and Kumar, C. A. (2012). Evaluation of Antiinflammatory Activity of some selected species of Asclepiadaceae Family. Int. J. Chem. Sci. 10 (1), 548-556.

Kumar, P., Rani, S., Arunjyothi, B., Chakrapani, P., and Rojarani, A. (2017). Evaluation of Antidiabetic Activity of Gymnema sylvestre and Andrographis paniculata in Streptozotocin Induced Diabetic Rats. Int. J. Pharmacogn. Phytoch. Res. 9 (1), 22-25. doi: 10.25258/ijpapr.v9i1.8034

Kumar, P., Venkataranganna, M., Manjunath, K., Viswanatha, G., and Ashok, G. (2016). Methanolic leaf extract of Gymnema sylvestre augments glucose uptake and ameliorates insulin resistance by upregulating GLUT-4, PPAR- and adiponectin and leptin levels In vitro. J. Intercult. Ethnopharmacol. 5 (2), $146-$ 152. doi: $10.5455 /$ jice. 20160224051727

Kumar, S. N., Mani, U. V., and Mani, I. (2010). An Open Label Study on the Supplementation of Gymnema sylvestre in Type 2 Diabetics. J. Die. Suppl. 7 (3), 273-282. doi: 10.3109/19390211.2010.505901

Kumar, S., Paul, S., Walia, Y., Kumar, A., and Singhal, P. (2015). Therapeutic Potential of Medicinal Plants: A Review. J. Biol. Chem. Chron. 1, 46-54.

Kumar, V. H., Nayak, I. N., Huilgol, S. V., Yendigeri, S. M., and Narendar, K. (2015). Antidiabetic and hypolipidemic activity of Gymnema sylvestre in dexamethasone induced insulin resistance in Albino rats. Int. J. Med. Res. Health Sci. 4 (3), 639-645. doi: 10.5958/2319-5886.2015.00122.8

Kumar, V., Bhandari, U., Tripathi, C., and Khanna, G. (2013). Anti-obesity Effect of Gymnema sylvestre Extract on High Fat Diet-induced Obesity in Wistar Rats. Drug Res. 63 (12), 625-632. doi: 10.1055/s-0033-1349852

Li, Y., Zheng, M., Zhai, X., Huang, Y., Khalid, A., Malik, A., et al. (2015). Effect of Gymnema sylvestre, Citrullus colocynthis and Artemisia absinthium on blood glucose and lipid profile in diabetic human. Acta Pol. Pharm. 72, 981-985.

Liu, B., Asare-Anane, H., Al-Romaiyan, A., Huang, G., Amiel, S. A., Jones, P. M., et al. (2009). Characterisation of the Insulinotropic Activity of an Aqueous Extract of Gymnema sylvestre in Mouse $\beta$-Cells and Human Islets of Langerhans. Cell. Physiol. Biochem. 23 (1-3), 125-132. doi: 10.1159/000204101

Liu, H., Kiuchi, F., and Tsuda, Y. (1992). Isolation and Structure Elucidation of Gymnemic Acids, Antisweet Principles of Gymnema sylvestre. Chem. Pharm. Bull. 40 (6), 1366-1375. doi: 10.1248/cpb.40.1366

Liu, X., Ye, W., Yu, B., Zhao, S., Wu, H., and Che, C. (2004). Two new flavonol glycosides from Gymnema sylvestre and Euphorbia ebracteolata. Carbohydr. Res. 339 (4), 891-895. doi: 10.1016/j.carres.2003.12.017

Liu, Y., Xu, T.-H., Zhang, M.-Q., Li, X., Xu, Y.-J., Jiang, H.-Y., et al. (2014). Chemical constituents from the stems of Gymnema sylvestre. Chin. J. Nat. Med. 12 (4), 300-304. doi: 10.1016/S1875-5364(14)60059-5

Luo, H., Kashiwagi, A., Shibahara, T., and Yamada, K. (2006). Decreased bodyweight without rebound and regulated lipoprotein metabolism by gymnemate in genetic multifactor syndrome animal. Mol. Cell Biochem. 299 (1-2), 93-98. doi: 10.1007/s11010-005-9049-7

Malik, J. K., Manvi., F. V., Nanjware, B. R., Dwivedi, D. K., Purohit, P., and Chouhan, S. (2010). Anti-arthritic activity of leaves of Gymnema sylvestre R.Br. leaves in rats. Pharm. Lett. 2, 336-341.

Mall, G. K., Mishra, P. K., and Prakash, V. (2009). Antidiabetic and hypolipidemic activity of Gymnema sylvestre in alloxan induced diabetic rats. Glob. J. Biotech. Biochem. 4 (1), 37-42.

Mao, Q. (2005). Role of the breast cancer resistance protein (ABCG2) in drug transport. AAPS J. 7 (1), E118-E133. doi: 10.1208/aapsj070112

Marakis, G., Ziegenhagen, R., Lampen, A., and Hirsch-Ernst, K. I. (2018). Risk assessment of substances used in food supplements: the example of the botanical Gymnema sylvestre. EFSA Journal 16 (51), e16083. doi: 10.2903/j. efsa.2018.e16083

Mathew, M. (2004). Aromatic and Medicinal Plants Research Station, Odakkali-A Centre for Promoting Medicinal and Aromatic Plants. Indian Coconut J. Cochin 34 (10), 10-15.

Matsuda, H., Murakami, T., Ninomiya, K., Inadzuki, M., and Yoshikawa, M. (1997). New hepatoprotective saponins, bupleurosides III, VI, IX, and XIII, from Chinese Bupleuri Radix: Structure-requirements for the cytoprotective activity in primary cultured rat hepatocytes. Bioorg. Med. Chem. Lett. 7 (17), 2193-2198. doi: 10.1016/S0960-894X(97)00418-6

Mcburney, D. H., and Gent, J. F. (1978). Taste of methyl- $\alpha$-D-mannopyranoside: Effects of cross adaptation and Gymnema sylvestre. Chem. Senses 3 (1), 45-50. doi: 10.1093/chemse/3.1.45

Nadkarni K. M. editor. (1996). "Indian materia medica," in Dr. KM Nadkarnis Indian materia medica: with Ayurvedic, Unani-Tibbi, Siddha, allopathic, homeopathic, naturopathic \& home remedies, appendices \& indexes, vol. 1 (Popular Prakashan).

Nadkarni, K. M. (1986). "Gymnema sylvestre," in Indian Materia Medica with Ayurvedic Unani, vol.I (Bombay, India: Popular Prakashan), 596-599.

Najafi, S., and Deokule, S. S. (2011). Studies on Gymnema sylvestre-a medicinally important plant of the family Asclepiadaceae. Trakia. J. Sci. 9 (2), 26-32.

Nakamura, Y., Tsumura, Y., Tonogai, Y., and Shibata, T. (1999). Fecal Steroid Excretion is Increased in Rats by Oral Administration of Gymnemic Acids Contained in Gymnema sylvestre Leaves. J. Nutr. 129 (6), 1214-1222. doi: $10.1093 /$ jn $/ 129.6 .1214$

Ogawa, Y., Sekita, K., Umemura, T., Saito, M., Ono, A., Kawasaki, Y., et al. (2004). Gymnema sylvestre Leaf Extract: A 52-Week Dietary Toxicity Study in Wistar Rats. J. Food Hyg. Soc. JPN. 45 (1), 8-18. doi: 10.3358/ shokueishi.45.8

Ohmori, R., Iwamoto, T., Tago, M., Takeo, T., Unno, T., Itakura, H., et al. (2005). Antioxidant activity of various teas against free radicals and LDL oxidation. Lipids 40 (8), 849-853. doi: 10.1007/s11745-005-1447-4

Pasha, C., Sayeed, S., Ali, M. S., and Khan, M. Z. (2009). Antisalmonella Activity of Selected Medicinal Plants. Turkish J. Biol. 33, 59-64. doi: 10.3906/biy-0804-3

Patel, M. R. (2017). Pharmacognostic and Phytochemical Evaluation of Gymnema sylvestre Leaf. World J. Pharm. Pharm. Sci. 6 (7), 1532-1538. doi: 10.20959/ wjpps20177-9574

Paul, J., and Jayapriya, K. P. (2009). Screening of antibacterial effects of Gymnema sylvestre (L.) R.Br. - A medicinal plant. Pharmacol. online 3, 832-836.

Porchezhian, E., and Dobriyal, R. M. (2003). An overview on the advances of Gymnema sylvestre: chemistry, pharmacology and patents. Pharmazie 58 (1), 5-12. doi: 10.1002/chin.200319223

Potawale, S. E., Shinde, V. M., Libi, A., Boradem, S., Dhalawatm, H., and Deshmukh, R. S. (2008). Gymnema sylvestre: a comprehensive review. Pharmacol. online 2, 144-157.

Pramanick, D. D. (2016). "Anatomical studies on the leaf of Gymnema sylvestre (Retz.) R. Br. ex Schult. (Apocynaceae)," in A magical herbal medicine for diabetes. Int. J. Herb. Med. 4 (1), 70-72.

Preuss, H. G., Garis, R. I., Bramble, J. D., Bagchi, D., Bagchi, M., Rao, C. V., and Satyanarayana, S. (2005). Efficacy of a novel calcium/potassium salt of (-)-hydroxycitric acid in weight control. Int. J. Clin. Pharmacol. Res. 25 (3), 133-144.

Rachh, P. R., Patel, S. R., Hirpara, H. V., Rupareliya, M. T., Rachh, M. R., Bhargava, A. S., et al. (2009). In-vitro evaluation of antioxidant activity of Gymnema sylvestre R.Br. leaf extract. Rom. J. Biol. Plant Biol. 54 (2), 141-148.

Rachh, P., Rachh, M., Ghadiya, N., Modi, D., Modi, K., Patel, N., et al. (2010). Antihyperlipidemic Activity of Gymenma sylvestre R. Br. Leaf Extract on Rats Fed with High Cholesterol Diet. Int. J. Pharmacol. 6 (2), 138-141. doi: 10.3923/ ijp.2010.138.141

Rahman, M. M., Habib, M. R., Hasan, M. A., Saha, A., and Mannan, A. (2014). Comparative assessment on In vitro antioxidant activities of ethanol extracts of Averrhoa bilimbi, Gymnema sylvestre and Capsicum frutescens. Pharmacog. Res. 6, 36-41. doi: 10.4103/0974-8490.122915

Ramalingam, R., Dhand, C., Leung, C. M., Ong, S. T., Annamalai, S. K., Kamruddin, M., et al. (2019). Antimicrobial properties and biocompatibility of electrospun poly- $\varepsilon$-caprolactone fibrous mats containing Gymnema sylvestre leaf extract. Mat. Sci. Eng. 98, 503-514. doi: 10.1016/j.msec.2018.12.135

Rouhi, S. Z. T., Sarker, M. M. R., Rahmat, A., Alkahtani, S. A., and Othman, F. (2017). The effect of pomegranate fresh juice versus pomegranate seed powder on metabolic indices, lipid profile, inflammatory biomarkers, and the histopathology of pancreatic islets of Langerhans in streptozotocinnicotinamide induced type 2 diabetic Sprague-Dawley rats. BMC Complement. Altern. Med. 17 (1), 156. doi: 10.1186/s12906-017-1724-1

Rupanar, S. V., Pingale, S. S., Dandge, C. N., and Kshirsagar, D. (2012). Phytochemical screening and In vitro evaluation of antioxidant antimicrobial 
activity of Gymnema sylvestre. Int. J. curr. Res. 8 (12), 43480-43486. doi: 10.7897/2230-8407.080327

Sahu, N., Mahato, S. B., Sarkar, S. K., and Poddar, G. (1996). Triterpenoid saponis from Gymnema sylvestre. Phytochem. 41, 1181-1185. doi: 10.1016/ 0031-9422(95)00782-2

Sarker, M. M. R. (2015). Antihyperglycemic, insulin-sensitivity and antihyperlipidemic potential of Ganoderma lucidum, a dietary mushroom, on zalloxan-and glucocorticoid-induced diabetic Long-Evans rats. Funct. Food Health Dis. 5 (12), 450-466. doi: 10.31989/ffhd.v5i12.220

Sarker, M. M. R., Mazumder, M. E. H., and Rashid, M. H. O. (2011). In vitro enhancement of polyclonal IgM production by ethanolic extract of Nigella sativa L. seeds in whole spleen cells of female BALB/c mice. Bangladesh Pharm. J. 14 (1), 73-77.

Sarker, M. M. R., Nahar, S., Shahriar, M., Seraj, S., and Choudhuri, M. S. K. (2012a). Preliminary study of the immunostimulating activity of an ayurvedic preparation, Kanakasava, on the splenic cells of $\mathrm{BALB} / \mathrm{c}$ mice in vitro. Pharm. Biol. 50 (11), 1467-1472. doi: 10.3109/13880209.2012.681329

Sarker, M. M. R., Nimmi, I., and Kawsar, M. H. (2012b). Preliminary screening of six popular fruits of Bangladesh for in vitro IgM production and proliferation of splenocytes. Bangladesh Pharm. J. 15 (1), 31-37.

Sarker, M. M. R., and Gohda, E. (2013). Promotion of anti-keyhole limpet hemocyanin IgM and IgG antibody productions in vitro by red bell pepper extract. J. Funct. Foods 5 (4), 1918-1926.

Sastry, B. S. (1994). Gymnema sylvestre. Chaukhambha, Varanasi, India: Bhav Prakash Nighantu.

Sathya, S., Kokilavani, R., and Gurusamy, K. (2008). Hypoglycemic effect of Gymnema sylvestre (retz.), R. Br leaf in normal and alloxan induced diabetic rats. Anc. Sci. Life 28 (2), 12-14.

Senthilkumar, M. (2015). Phytochemical Screening and Antibacterial Activity of Gymnema sylvestre R.Br. Ex Schult. Int. J. Pharm. Sci. Res. 6 (6), 2496-2503. doi: 10.13040/IJPSR.0975-8232.6(6).2496-03

Shafey, A. A., El-Ezabi, M. M., Seliem, M. M., Ouda, H. H., and Ibrahim, D. S. (2013). Effect of Gymnema sylvestre R. Br. leaves extract on certain physiological parameters of diabetic rats. J. King Saud. Univ. Sci. 25 (2), 135-141. doi: 10.1016/j.jksus.2012.11.001

Shah, K. K., Shiradkar, M. R., and Bindu, V. H. (2012). In vitro permeation of aceclofenac through the shed skin of two different species. Der. Pharmacia Sinic. 3, 11-19.

Shah, K. K., Shiradkar, M. R., and Hima Bindu, V. (2011). Transdermal delivery of aceclofenac: Effect of Gymnema sylvestre and Caralluma adscendens with its mechanism of action. Res. J. Pharm. Biol. Chem. Sci. 2, 762-772.

Shah, M. A., Sarker, M. M. R., and Gousuddin, M. (2016). Antidiabetic potential of Brassica Oleracea Var. Italica in type 2 diabetic sprague dawley (sd) rats. Int. J. Pharmacogn. Phytochem. Res. 8 (3), 462-469.

Shankar, K. R., and Rao, B. G. (2008). Anti-arthritic activity of Gymnema sylvestre root extract. Biosci. Biotechnol. Res. Asia 5 (1), 469-471.

Shanmugasundaram, E. R. B., Venkatasubrahmanyam, M., Vijendran, N., and Shanmugasundaram, K. R. (1988). Effect of an Isolate from Gymnema sylvestre, R. Br. in The Control of Diabetes Mellitus and The Associated Pathological Changes. Anc. Sci. Life 7 (3-4), 183-194.

Shanmugasundaram, E., Gopinath, K., Shanmugasundaram, K., and Rajendran, V. (1990a). Possible regeneration of the islets of langerhans in streptozotocindiabetic rats given Gymnema sylvestre leaf extracts. J. Ethnopharmacol. 30 (3), 265-279. doi: 10.1016/0378-8741(90)90106-4

Shanmugasundaram, E., Rajeswari, G., Baskaran, K., Kumar, B., Shanmugasundaram, K., and Ahmath, B. (1990b). Use of Gymnema sylvestre leaf extract in the control of blood glucose in insulin-dependent diabetes mellitus. J. Ethnopharmacol. 30 (3), 281-294. doi: 10.1016/0378-8741(90)90107-5

Sheikh, B. Y., Sarker, M. M. R., Kamarudin, M. N. A., and Ismail, A. (2017a). Prophetic medicine as potential functional food elements in the intervention of cancer: A review. Biomed. Pharmacother. 95, 614-648. doi: 10.1016/j.biopha.2017.08.043

Sheikh, B. Y., Sarker, M. M. R., Kamarudin, M. N. A., and Mohan, G. (2017b). Antiproliferative and apoptosis inducing effects of citral via 533 and ROS-induced mitochondrial-mediated apoptosis in human colorectal HCT116 and HT29 cell lines. Biomed. Pharmacother. 96, 834-846. doi: 10.1016/j.biopha.2017.10.038

Shenoy, R. S., Prashanth, K. V., and Manonmani, H. K. (2018). In vitro antidiabetic effects of isolated triterpene glycoside fraction from Gymnema sylvestre. J. Evid. Based Complement. Altern. Med. 2018, 1-12. doi: 10.1155/2018/7154702
Shigematsu, N., Asano, R., Shimosaka, M., and Okazaki, M. (2001a). Effect of administration with the extract of Gymnema sylvestre $\mathrm{R}$. Br leaves on lipid metabolism in rats. Biol. Pharm. Bull. 24 (6), 713-717. doi: 10.1248/bpb.24.713

Shigematsu, N., Asano, R., Shimosaka, M., and Okazaki, M. (2001b). Effect of long term-administration with Gymnema sylvestre R. BR on Plasma and Liver Lipid in Rats. Biol. Pharm. Bull. 24 (6), 643-649. doi: 10.1248/bpb.24.643

Shimizu, K., Iino, A., Nakajima, J., Tanaka, K., Nakajyo, S., Urakawa, N., et al. (1997). Suppression of glucose absorption by some fractions extracted from Gymnema sylvestre Leaves. J. Vet. Med. Sci. 59 (4), 245-251. doi: 10.1292/jvms.59.245

Shivanna, Y., and Raveesha, K. A. (2009). In01-vitro antibacterial effect of selected medicinal plant extracts. J. Nat. Prod. (India) 2, 64-69.

Shiyovich, A., Nesher, L., and Sztarkier, I. (2010). Toxic hepatitis induced by Gymnema sylvestre, a natural remedy for type 2 diabetes mellitus. Am. J. Med. Sci. 340 (6), 514-517. doi: 10.1097/MAJ.0b013e3181f41168

Singh, D. K., Kumar, N., Sachan, A., Lakhani, P., Tutu, S., Nath, R., et al. (2017). Hypolipidaemic effects of Gymnema sylvestre on high fat diet induced dyslipidaemia in wistar rats. J. Clin. Diagn. Res. 11 (5), FF01-FF05. doi: 10.7860/JCDR/2017/27430.9859

Singh, V.K., Dwivedi, P., Chaudhary, B. R., and Singh, R. (2015). Immunomodulatory effect of Gymnema sylvestre (R.Br.) Leaf Extract: an in vitro study in rat model. PLoS One 10 (10), 1-15. doi: 10.1371/journal.pone.0139631

Singh, V. K., Umar, S., Ansari, S. A., and Iqbal, M. (2008). Gymnema sylvestre for diabetics. Journal of Herbs. J. Herbs Spices Med. Plants 14 (1-2), 88-106. doi: 10.1080/10496470802341508

Sinsheimer, J. E., Rao, G. S., and Mcilhenny, H. M. (1970). Constituents from Gymnema sylvestre leaves V: isolation and preliminary characterization of the gymnemic acids. J. Pharm. Sci. 59 (5), 622-628. doi: 10.1002/jps.2600590510

Somani, R., Deshmukh, P., Shah, P., Soni, R., Jain, D., and Khaserao, S. (2013). Prokinetic effect of hyponidd, a herbomineral formulation in STZ- induced diabetic rats. Pharmacologia 4 (1), 48-52. doi: 10.5567/pharmacologia.2013.48.52

Srikanth, A. V., Sayeeda, M., Lakshmi, N., Ravi, M., Kumar, P., and Madhava, R. B. (2010). Anticancer activity of Gymnema sylvestre R.Br. Int. J. Pharm. Sci. Nanotech. 3, 897-899.

Srivastava, Y., Venkatakrishna-Bhatt, H., Jhala, C. I., Nigam, S. K., Kumar, A., Verma, Y., et al. (1986). Oral Gymnema sylvestre R.Br. Leaf Extracts Inducing Protracted Longevity and Hypoglycemia in Alloxan Diabetic Rats: Review and Experimental Study. Int. J. Crude Drug Res. 24 (4), 171-176. doi: $10.3109 / 13880208609060895$

Srividya, A. R., Varma, S., Dhanapal, S. P., Vadivelan, R., and Vijayan, P. (2010). In vitro and in vivo evaluation of hepatoprotective activity of Gymnema sylvestre. Int. J. Pharm. Sci. Nanotechnol. 2, 768-773.

Sugihara, Y., Nojima, H., Matsuda, H., Murakami, T., Yoshikawa, M., and Kimura, I. (2000). Antihyperglycemic effects of gymnemic acid IV, a compound derived from Gymnema sylvestre leaves in streptozotocin-diabetic mice. J. Asian Nat. Prod. Res. 2 (4), 321-327. doi: 10.1080/10286020008041372

Sujin, R. M. (2008). Anti-diabetic effect of Gymnema sylvestre (asclepiadaceae) powder in the stomach of rats. Ethnobot. Leaflets 12, 1158-1167.

Swami, J., and Prabakaran, (2012). Studies on antibacterial activity of Gymnema sylvestre against respiratory infection causing bacteria. Int. J. Curr. Adv. Res. 1 (1), $1-4$.

Swetha, Y., Sunanda, , Rajanikar, , Reddy, A. K., Srivally, , and Masoom, M. (2012). Phytochemical and pharmacological studies of methanolic extract of Gymnema sylvestre leaves: an approach for in vivo antiulcer activity. Res. J. Pharmacol. Pharmacodyn. 4 (6), 368-372.

Tahir, M., Rasheed, M. A., Niaz, Q., Ashraf, M., Anjum, A. A., and Ahmed, M. U. (2017). Evaluation of antibacterial effect of Gymnema sylvestre R.Br. species cultivated in Pakistan. Pak. Vet. J. 37 (3), 245-250.

Tamaki, H., Satoh, H., Hori, S., Ohtani, H., and Sawada, Y. (2010). Inhibitory effects of herbal extracts on breast cancer resistance protein (BCRP) and structureInhibitory Potency Relationship of Isoflavonoids. Drug Metab. Pharmacok. 25 (2), 170-179. doi: 10.2133/dmpk.25.170

Thanwar, M., Dwivedi, D., Gharia, D., and Chouhan, S. (2016). Antibacterial study of Gymnema sylvestre plant. Int. J. Chem. 4 (3), 80-83.

The Plant List. (2013). Version 1.1. Published on the Internet; http://www. theplantlist.org/(accessed 20th June 2019).

Tiwari, P., Mishra, B. N., and Sangwan, N. S. (2014). Phytochemical and pharmacological properties of Gymnema sylvestre: An important medicinal plant. Biomed. Res. Int. 2014, 1-18. doi: 10.1155/2014/830285 
Wu, X., Mao, G., Fan, Q., Zhao, T., Zhao, J., Li, F., et al. (2012). Isolation, purification, immunological and anti-tumor activities of polysaccharides from Gymnema sylvestre. Food. Res. Int. 48 (2), 935-939. doi: 10.1016/j.foodres.2012.02.006

Yasmin, H., Kaiser, M. A., Sarker, M. M. R., Rahman, M. S., and Rashid, M. A. (2009). Preliminary anti-bacterial activity of some indigenous plants of Bangladesh. Dhaka Univ. J. Pharm. Sci. 8 (1), 61-65. doi: 10.3329/dujps.v8i1.5337

Yasukawa, K., Okuda, S., and Nobushi, Y. (2014). Inhibitory effects of Gymnema (Gymnema sylvestre) leaves on tumour promotion in two-stage mouse skin carcinogenesis. J. Evid. Based Complement. Altern. Med. 2014, 1-5. doi: $10.1155 / 2014 / 328684$

Ye, W., Zhang, Q., Liu, X., Che, C., and Zhao, S. (2000). Oleanane saponins from Gymnema sylvestre. Phytochemistry 53 (8), 893-899. doi: 10.1016/ S0031-9422(99)00483-5

Yogi, B., and Mishra, A. (2016). Hepatoprotective effects of polyherbal formulation against carbon tetrachloride-induced hepatic injury in albino rats: a toxicity screening approach. Asian J. Pharm. Clin. Res. 10 (1), 192-198. doi: 10.22159/ ajpcr.2017.v10i1.14757

Yoshikawa, K., Kondo, Y., Arihara, S., and Matsuura, K. (1993). Antisweet natural products IX structures of gymnemic acids XV-XVIII from Gymnema sylvestre R. Br. Chem. Pharm. Bull. 41 (12), 1730-1732. doi: 10.1248/cpb.41.1730

Yoshikawa, M., Murakami, T., and Matsuda, H. (1997). Medicinal foodstuffs. X. Structures of new triterpene glycosides, gymnemosides-c,-d,-e, and-f, from the leaves of Gymnema sylvestre R. Br.: influence of gymnema glycosides on glucose uptake in rat small intestinal fragments. Chem. Pharm. Bull. 45 (12), 2034-2038. doi: 10.1248/cpb.45.2034

Yoshikawa, M., Murakami, T., Kadoya, M., Li, Y., Murakami, N., Yamahara, J., et al. (1998). ChemInform abstract: medicinal foodstuffs. Part 9. The inhibitors of glucose absorption from the leaves of Gymnema sylvestre R. BR. (Asclepiadaceae): Structures of Gymnemosides a and b. Chem. Inform. 29 (12). doi: 10.1002/chin.199812156

Zuñiga, L. Y., González-Ortiz, M., and Martínez-Abundis, E. (2017). Effect of Gymnema sylvestre administration on metabolic syndrome, insulin sensitivity, and insulin secretion. J. Med. Food 20 (8), 750-754. doi: 10.1089/ jmf.2017.0001

Conflict of Interest: The authors declare that the research was conducted in the absence of any commercial or financial relationships that could be construed as a potential conflict of interest.

Copyright (c) 2019 Khan, Sarker, Ming, Mohamed, Zhao, Sheikh, Tsong and Rashid. This is an open-access article distributed under the terms of the Creative Commons Attribution License (CC BY). The use, distribution or reproduction in other forums is permitted, provided the original author(s) and the copyright owner(s) are credited and that the original publication in this journal is cited, in accordance with accepted academic practice. No use, distribution or reproduction is permitted which does not comply with these terms. 